\title{
AN EGOLOGICAL STUDY OF THE VEGETATION IN THREE FORMER RIVER BEDS
}

\author{
W. A. E. VAN DONSELAAR - TEN BOKKEL HUININK \\ Botanical Museum and Herbarium, Utrecht) \\ (R.I.V.O.N.-Communication nr. 93) \\ (received January, 6th, 1961)
}

\section{GONTENTS}

I. INTRODUCTION . . . . . . . . . . . . . . . 113

II. The "KiL" near Hurwenen. . . . . . . . . . . . . . 115

1. Introductory remarks . . . . . . . . . ... 115

2. Description of the vegetation . . . . . . 117

2.1. Potamion . . . . . : : 117

2. 2. Scirpeto-Phragmitetum . . . . . . . . . . 120

2. 3. Caricetum gracilis-vesicariae . . . . . . . . . . 122

3. Factors responsible for the differentiation of the vegetation . . . 123

3. 1. Abiotic factors . . . . . . . . . . . . . 123

3. 1.1. Light . . . . . . . . . . 123

3. 1.2. Wind . . . . . . . . . . . . 123

3. 1.3. Depth of water . . . . . . . . . . 124

3. 1.4. Consistence of the soil . . . . . 127

3. 1.5. Chemical and physical properties of the water $: 128$

3.1.5.1. $\mathrm{P}_{\mathrm{H}}$ of the water .................. 128

3.1.5.2. $\mathrm{O}_{2}$-content of the water. . . . . . 128

3. 2. Biotic factors . . . . . . . . . . . . . . . . 129

3. 2. 1. Mode of rooting . . . . . . . . . . . . . . . . . . 129

3.2. 2. Preceding stages in the succession.. .2136

4. The transformation of water into land ......... 146

5. Time required for the transformation of water into land . . . . 147

III. The "WIEL" NEAR TUIL. . . . . . . . . . . . . . . 149

1. Introductory remarks . . . . . . . . . . . . . 149

2. Description of the vegetation.$\cdots 150$

2.1. Potamion . . . . . : : : 150

2. 2. Scirpeto-Phragmitetum . . . . . . . . . . 150

2. 3. Stands of Carex riparia . . . . . . . . . . . . . 150

2. 4. Alnetum glutinosae . . . . . . . . . . . 152

3. Factors responsible for the differentiation of the vegetation . . . 152

3. 1. Abiotic factors................ 152

3. 1. 1. Depth of water . . . . . . . . . 152

3. 1.2. Consistence of the soil . . . . . . . . . 152

3.1.3. Composition of the soil . . . . 153

3. 1.4. Chemical and physical properties of the water . . 153

3. 2. Biotic factors . . . . . . . . . . . . . 153

3. 2. 1. Mode of rooting . . . . . . 153

3.2.2. Preceding stages in the succession..$\cdots 154$

4. The transformation of water into land . . . . . . 155

IV. The "KIL" NEAR WAardenburg . . . . . . . . . . 156

1. Introductory remarks . . . . . . . . . . . . . . . 156

2. Description of the vegetation .............. 156 
2. 1. Potamion . . . . . . . . . . . . . . . . 156

2. 2. Scirpeto-Phragmitetum and Caricetum gracilis-vesicariae . . 156

3. Factors responsible for the differentiation of the vegetation . . . 156

V. Discussion OF THE FAGTORS BY WHICH THE DIFPERENTIATION IN THE VEGETATION IN THE FORMER RIVER BEDS IS DETERMINED . . . . . .

VI. DiscuSSION OF THE FACTORS BY WHICH THE DIFFERENCES BETWEEN THE VEGETATION IN THE VARIOUS FORMER RIVER BEDS ARE DETERMINED . . 158

VII. SUMmARY . . . . . . . . . . . . . . . 160

REFERENCES ................... 161

\section{INTRODUGTION}

In the years 1954, 1955 and 1956 the "Foundation for Biocenological Research" ("Stichting tot Onderzoek van Levensgemeenschappen: S.O.L.") studied the vegetation found in former beds of the larger rivers by which the Netherlands are traversed. One of the aims of this investigation was to establish, in broad outline, the nature of the correlation existing between the various types of vegetation developing in these former river beds, and the environmental factors which exercised their influence on the latter.

In the summer of 1955 , in connection with this investigation, the correlation meant in the preceding paragraph was studied somewhat more circumstantially in three former river beds of the river "Waal" situated near Zaltbommel, viz. the "Kil" near Hurwenen, the "Kil" near Waardenburg, and the "Wiel" near Tuil (cf. Fig. 1). The two "Kils" are situated outside the main dike, the "Wiel" inside the latter. It was thought that a comparison of the vegetation found in these three former river beds would give us a better insight into the factors that are responsible for the differences between the types of vegetation found in them.

The vegetation of the former river beds near Hurwenen and near Tuil will be described in some detail, and an analysis will be given of the environmental factors of which it may reasonably be assumed that they will have played a part in the differentiation of the vegetation in these two beds. The former river bed near Waardenburg will be used only as a means to test the conclusions arrived at by the comparison of the other two.

The choice of the factors that were to be taken into account, was based on the following considerations.

Climatic factors. Within an area of limited extent, where therefore but one macro-climate is found, the differences in the vegetation, in so far as they are caused by climatic factors, must be due to differences in the micro-climate. The factors which in the micro-climate of the former river beds may play a part in the differentiation of the vegetation, are light and wind force. The amount of precipitation and the humidity of the atmosphere, two factors which elsewhere play an important part in the differentiation of the vegetation, are, so far as we can judge at presence, of no importance in a wet environment. 


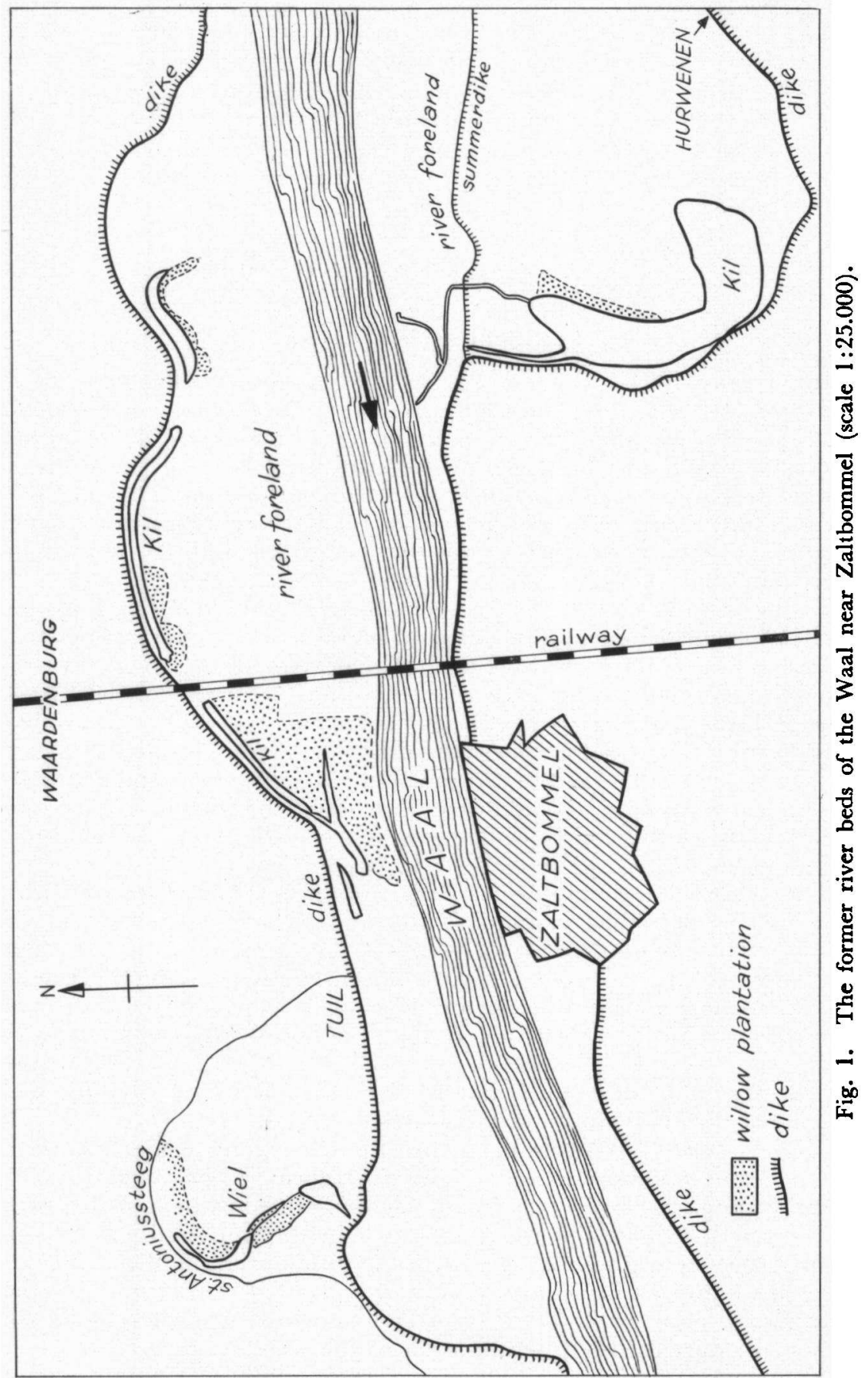


Edaphic factors. In the former river beds which form the subject of this investigation, the soil consists of clay. In part of the "Wiel" near Tuil the latter is covered by a layer of peat of which the thickness is not everywhere the same. The structure of the soil is of importance to those plants that send their roots into the latter. Next to the structure of the soil, various features of the mass of water through which the plants have to pass in order to reach the surface, play here an important part, viz. the chemical composition, the $\mathrm{p}_{\mathrm{H}}$, the $\mathrm{O}_{2}$-concentration, and the depth. This will need no further comment.

Other factors. It is well-known that in an environment showing extreme conditions, the way in which a plant is rooted, and in which its root system is differentiated, determines its local distribution, and may also determine its competing value. For this reason special attention was paid to the root system.

Man interferes directly in the development of the vegetation by mowing and by the grazing of his cattle, and indirectly by the way in which he regulates the water supply.

That preceding stages in the development of the vegetation exercise an influence on the composition of the present one, is generally admitted. The history of the vegetation of these former river beds was reconstructed therefore by means of plant remains found in the soil, and by means of features revealed in aerial photographs taken at various dates.

Special attention was paid in this study to the depth of the water, the development of the root systems, and the nature of the preceding stages in the development of the vegetation.

\section{THE "KIL" NEAR HURWENEN}

\section{INTRODUCTORY REMARKS}

The "Kil" near Hurwenen (Fig. 1) owes its origin to a former bent in the river "Waal"; this loop was cut off in the seventeenth century. It is situated to the east of Zaltbommel and south of the present river bed. Old maps preserved in the "Maarten van Rossumhuis", a regional museum at Zaltbommel, show that in 1600 the main stream still passed through this loop. On maps dating from the end of the seventeenth century it appears that the river subsequently took a shortcut. At present the former river bed is separated from the river by a summer dike and comparatively high riverforeland meadows. A ditch provided with a miniature sluice now forms the only connection with the river. When the latter reaches a high level, the area round the former river bed is flooded. This happens regularly.

The "Kil" of Hurwenen is one of the finest examples of an old river bed to be found in the Netherlands. It is situated just outside the main dike and separated from the river by comparatively high, flowery meadows. Unfortunately a large part of these foreland meadows has been cleared away for the winning of sand. However, the greatest attraction is found in the vegetation of the former river bed itself. It 

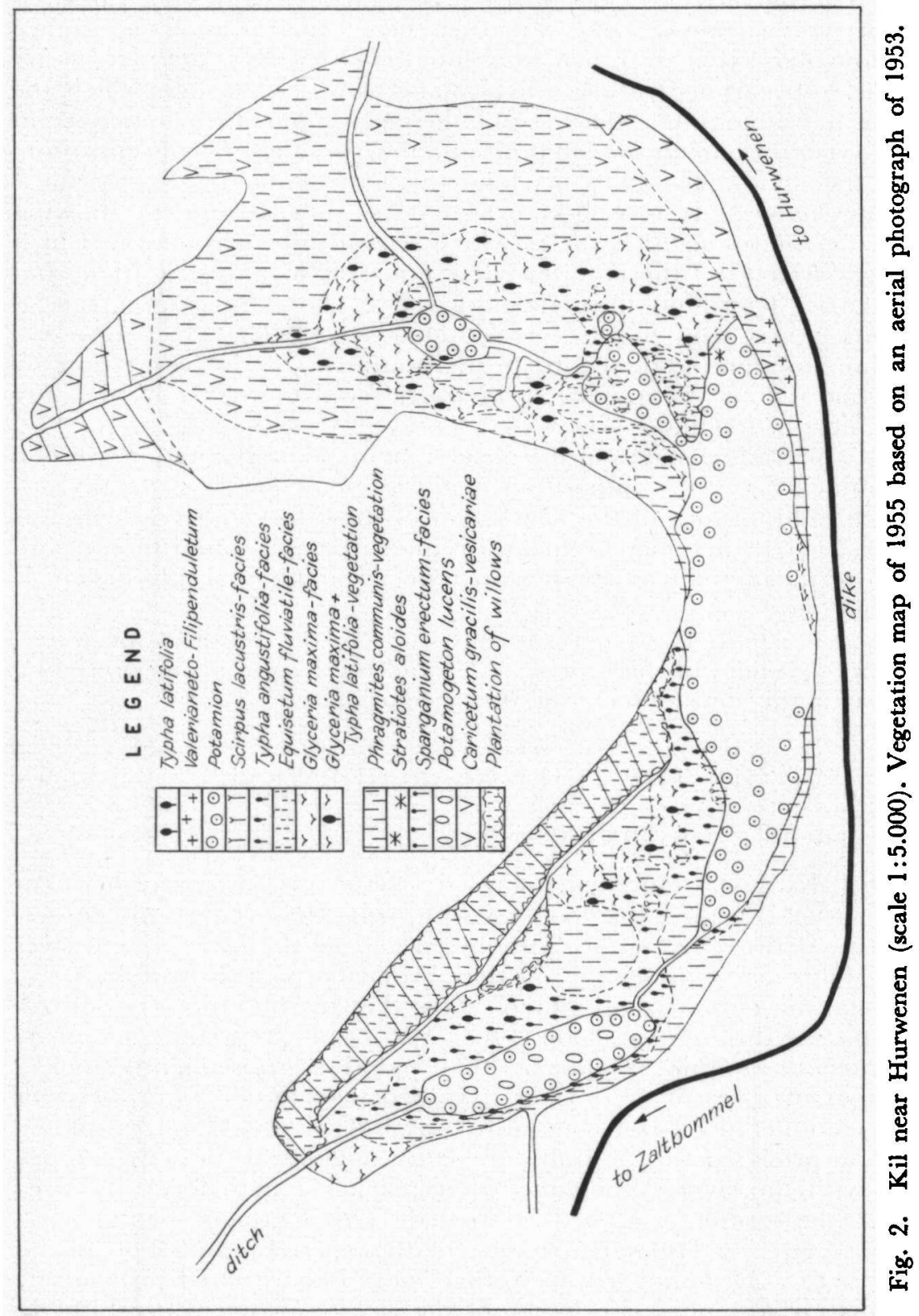
presents us with a complete picture of open water which gradually changes into a tract of reed with a more or less dry soil.

\section{DESCRIPTION OF THE VEGETATION}

Because of the regular inundations during periods of flood the water in a former river bed situated outside the main dike of the present river, always remains eutrophic, and the vegetation therefore eutraphentous.

The communities of hydrophytes belong to the Potamion eurosibiricum Koch 1926. This vegetation is bordered by the ScirpetoPhragmitetum medio-europaeum (Koch 1926) Tx. 1941, an association belonging to the Phragmition eurosibiricum (Koch 1926) Tx. $1942 \mathrm{em}$. $\mathrm{Br}-\mathrm{Bl}$. et S. 1942, and on the landward side the latter is replaced by the Caricetum gracilis-vesicariae Westhoff 1949, which belongs to the Magnocaricion elatae Koch 1926. With this community the natural development of the hydrosere stops, as at this stage so much silt has been deposited that the soil can be reclaimed for agricultural purposes (Fig. 2).

\section{1. Potamion}

Among the higher plants growing in the open water Potamogeton lucens extends to the deepest parts. It is almost entirely submersed the flowering spikes being the only parts which project above the surface. This vegetation may be included in the Potametum lucentis Hueck 1931. Where the depth of the water decreases, Potamogeton lucens becomes less abundant, probably because in these parts the light is intercepted by the floating leaves of $\mathcal{N} y$ mphaea alba and $\mathcal{N} u p h a r$ luteum. The few specimens that are found between these plants with floating leaves, are nevertheless vigorously developed and provided with long shoots.

Seen from afar $\mathcal{N}$ ymphaea alba, Nuphar luteum, and also $\mathcal{N} y$ mphoides peltata seem to form a homogeneous vegetation. However, within the latter each of the three species may locally become dominant, so that seen from nearby the vegetation appears to form a mosaic. The local dominance is due to the fact that there is a strong vegetative propagation by means of rhizomes. However, even before the latter sets in, or where it is less pronounced, the arrangement of the leaves in rosettes tends to create the impression of a mosaic. The rhizomes are often so densely interwoven that in punting a boat through this vegetation, the pole more often strikes a rhizome than that it sinks into the mud.

During the first part of the growth season the light still penetrates to the bottom, as at that time but few of the floating leaves have reached the surface; the other ones are still on their way, those of $\mathcal{N}$ uphar and $\mathcal{N}$ ymphaea with the edges rolled inwards, whereas those of Nymphoides are flat from the beginning. In most places the bottom is completely covered by leaves of Nuphar which are crumpled like lettuce. In July, when the vegetation shows its optimum development and the dominant species are in flower, nearly the whole surface is covered with floating leaves. Nymphaea, Nuphar and $\mathcal{N} y$ mphoides are 
Table 1

\begin{tabular}{|c|c|c|c|c|c|c|}
\hline $\begin{array}{l}\text { nr. of record } \\
\text { area in sq. m. } \\
\text { cover in \% } \% \text { in cm. } \\
\text { water depth }: \therefore:\end{array}$ & $\begin{array}{r}1 \\
50 \\
5 / 10 \\
90\end{array}$ & $\begin{array}{r}2 \\
12 \\
20 \\
70\end{array}$ & $\begin{array}{r}3 \\
25 \\
35 \\
50\end{array}$ & $\begin{array}{r}4 \\
10 \\
60 \\
60\end{array}$ & $\begin{array}{r}5 \\
4 \\
20 \\
50\end{array}$ & $\begin{array}{r}6 \\
6 \\
5 \\
70\end{array}$ \\
\hline 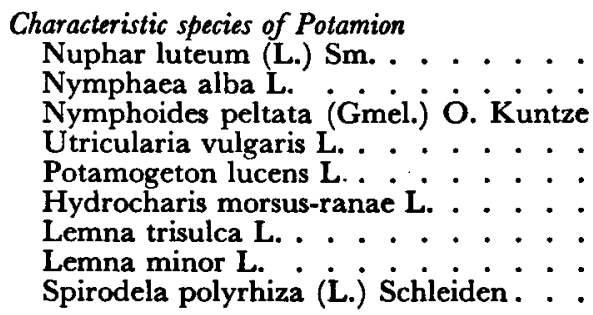 & $\begin{array}{r}2.2 \\
1.2 \\
1.2 \\
+.1 \\
+.1 \\
: \\
:\end{array}$ & $\begin{array}{c}1.2 \\
1.2 \\
\bullet \\
: \\
1.2 \\
1.2 \\
1.2 \\
1.2\end{array}$ & $\begin{array}{c}1.2 \\
: \\
: \\
+ \\
+ \\
\dot{0}\end{array}$ & $\begin{array}{c}2.2 \\
\dot{0} \\
2.2 \\
\dot{1} \\
1.2 \\
+.2 \\
\dot{0}\end{array}$ & $\begin{array}{c}+.2 \\
: \\
: \\
\vdots \\
:\end{array}$ & $\begin{array}{r}1.2 \\
: \\
+.1 \\
: \\
: \\
:\end{array}$ \\
\hline 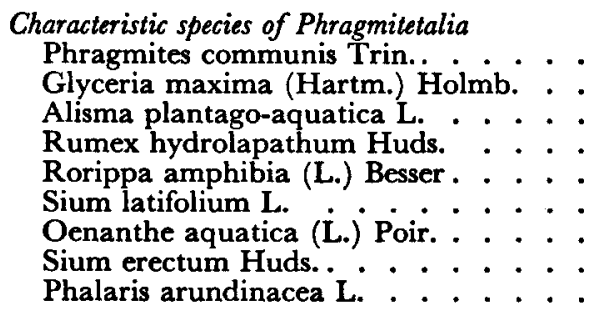 & $\dot{:}$ & $\begin{array}{c}+.1 \\
: \\
: \\
\vdots \\
\vdots \\
:\end{array}$ & $\begin{array}{r}: \\
+\dot{0} \\
1.2 \\
+.1 \\
: \\
:\end{array}$ & $\begin{array}{r}\dot{0} \\
\dot{0} \\
\dot{0} \\
\dot{0}\end{array}$ & $\begin{array}{c}2.2 \\
: \\
: \\
\vdots \\
:\end{array}$ & $\begin{array}{l}\dot{:} \\
\dot{:} \\
\dot{:} \\
\dot{:}\end{array}$ \\
\hline $\begin{array}{l}\text { Characteristic species of Phragmition and } \\
\text { Scirpeto-Phragmitetum } \\
\text { Scirpus lacustris L. ssp. lacustris . . } \\
\text { Typha angustifolia L. . } \\
\text { Typha latifolia L. } \\
\text { Sparganium erectum L. ssp. } \\
\text { polyedrum (A. et G.) Sch. et Th. } \\
\text { Butomus umbellatus L.. } \\
\text { Ranunculus lingua L. . . }\end{array}$ & : & $\begin{array}{r}\dot{\bullet} \\
+.2 \\
+.2 \\
\dot{\cdot}\end{array}$ & $\begin{array}{l}2.2 \\
\dot{1.2}\end{array}$ & $\begin{array}{c}4.2 \\
\dot{+} \\
+.2 \\
\dot{0}\end{array}$ & $\begin{array}{c}1.2 \\
1.2 \\
\bullet \\
+.2 \\
:\end{array}$ & $\begin{array}{l}\dot{ } \\
\dot{ } \\
2.2 \\
\dot{ }\end{array}$ \\
\hline $\begin{array}{l}\text { Characteristic species of Magnocaricion and } \\
\text { Garicetum gracilis-vesicariae } \\
\text { Carex acuta L. } \\
\text { Carex vesicaria L.: } \\
\text { Galium palustre L. } \\
\end{array}$ & $\dot{\bullet}$ & : & - & : & : & : \\
\hline 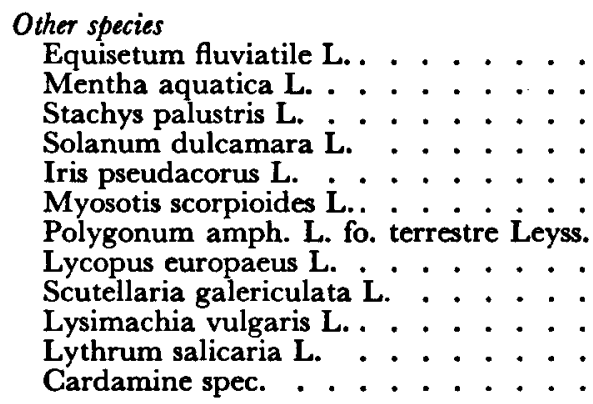 & $:$ & $\begin{array}{l}2.5 \\
: \\
: \\
: \\
: \\
:\end{array}$ & $\begin{array}{l}2.3 \\
\bullet \\
\bullet\end{array}$ & $\begin{array}{l}1.2 \\
: \\
: \\
: \\
:\end{array}$ & $\begin{array}{l}+.2 \\
: \\
: \\
: \\
:\end{array}$ & $\begin{array}{l}\dot{:} \\
\vdots \\
: \\
: \\
:\end{array}$ \\
\hline
\end{tabular}


AN ECOLOGICAL STUDY OF THE VEGETATION IN THREE FORMER RIVER BEDS 119

Kil near Hurwenen.

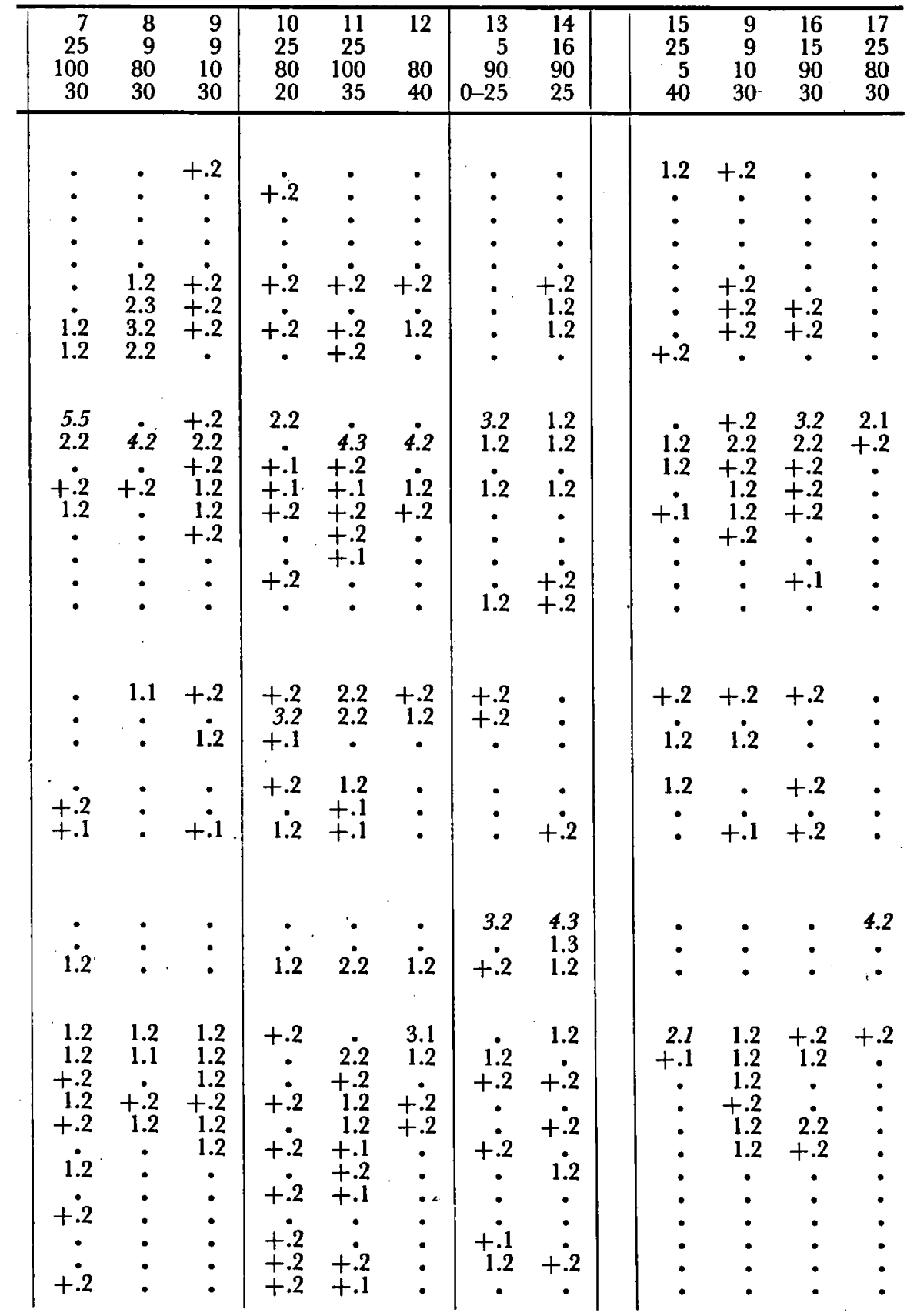

$\begin{array}{lll}\text { Supplement. } & \text { rec. } 16 \text { Epilobium hirsutum L. } & +.2 \\ & \text { rec. } 10 \text { Salix spec. } & +.1\end{array}$ 
in this case, apart from Potamogeton lucens, accompanied only by Utricularia vulgaris, whose yellow-flowered inflorescences rise above the water surface, and by a few individuals of Ceratophyllum demersum. Towards the end of the season the covering becomes less dense, as the floating leaves begin to decay, those of $\mathcal{N} u p h a r$ especially because they become perforated by the larvae of a beetle. At the end of August the vegetation already makes a somewhat dishevelled and dirty impression.

It is noteworthy that floating species, such as Lemnaceae and Hydrocharis morsus-ranae, are almost entirely absent. However, nearer to the bank, where helophytes raise their stems above the surface, they become more numerous, apparently because they are protected here against the wind.

Record 1 of table I gives a picture of the vegetation. It is not possible to refer the latter to a definite association, although it obviously is a community belonging to the Potamion eurosibiricum (cf. Westhoff e.a. 1946, Westhoff e.a. 1949, Van DonselaAr 1961). As it contains characteristic species of the Polygoneto-Nymphoidetum typicum van Donselaar 1961 as well as of the Myriophylleto-Nupharetum Koch 1926, it seems preferable to restrict ourselves to the statement that it belongs to the Potamion eurosibiricum Koch 1926. The Hydrochareto-Stratiotetum (v. Langendonck 1935) Kr. et Vl. 1937, which might have been expected in some of the more sheltered spots, proved to be entirely absent.

\section{2. Scirpeto-Phragmitetum}

The marginal vegetation which surrounds the Potamion and penetrates into the latter, belongs to the Scirpeto-Phragmitetum medioeuropaeum (Koch 1926) Tx. 1941, (Boer 1942, Westhoff e.a. 1946, v. Donselaar 1961). As the aspect of the vegetation in this zone is, from place to place, determined by local dominants, it does not look very homogeneous. However, when a number of records made in various parts of this zone, is brought together in the same table, the composition of the vegetation appears to be so constant that it seems allowed to regard the various stands as facies of the same association.

In the vegetation formed by $\mathcal{N} y$ mphaea and $N$ uphar some individuals of Scirpus lacustris or of Equisetum fluviatile appear as pioneers. Further towards the bank the erect stems of these plants approach each other more and more, and so above the surface of the water a closed vegetation develops in which these two species are dominant (records 2 and 3). The depth at which the facies of Scirpus lacustris and that of Equisetum fluviatile are found, varies between 70 and $50 \mathrm{~cm}$. Besides the dominants we find here Alisma plantago-aquatica, Rumex hydrolapathum, Rorippa amphibia and Mentha aquatica.

The outermost facies may also be one of Typha angustifolia (record 4), one of Phragmites communis (record 5) and one of Sparganium erectum ssp. polyedrum (record 6), but these facies are less often met with. The depth at which they occur, and the accompanying species are the same as 
those found in the facies of Scirpus lacustris and in that of Equisetum fluviatile.

Where the depth is less than $50 \mathrm{~cm}$. but more than $30 \mathrm{~cm}$., the pioneer facies passes into one with Phragmites communis (record 7) or by one with Glyceria maxima (record 8) as dominant species. Once in a while a vegetation is met with which consists for one half of $T y p h a$ angustifolia and for the other half of $T$. latifolia. As the depth of the water decreases, the number of accompanying species increases. Besides Scirpus lacustris, Equisetum fluviatile, Alisma plantago-aquatica, Rumex hydrolapathum, Rorippa amphibia and Mentha aquatica we then find Sium latifolium, Oenanthe aquatica, Butomus umbellatus, Ranunculus lingua, Galium palustre, Stachys palustris, Solanum dulcamara, Iris pseudacorus, Myosotis scorpioides and Polygonum amphibium fo. terrestre. Nuphar luteum, Nymphaea alba and Utricularia vulgaris appear to be confined to the pioneer facies.

In two places we found a vegetation in which all the species mentioned above were represented, but in which none of them reached dominance (record 9). In the following exposition we will use for this type the name "mixed vegetation".

Apart from the facies of the Scirpeto-Phragmitetum mentioned above, we also found in the "Kil" large "floating-mat vegetations", which we wish to include in the same association. In these "floating mats" one of the two Typha species, or both, dominate. The mass of roots and rhizomes extending is found at various depths from the surface of the water to $25 \mathrm{~cm}$ below the latter. It is often difficult or impossible to walk on these mats, and for this reason they are not directly influenced by human activities. In the vegetation of these floating mats most of the species of the Scirpeto-Phragmitetum prove to be represented, but because the top of the mat is found at the water surface or but slightly below the latter, in addition some species are met with which otherwise do not occur in the Scirpeto-Phragmitetum, but which belong to the Caricetum gracilis-vesicariae, so e.g. Galium palustre, Lycopus europaeus, Lysimachia vulgaris and Lythrum salicaria. On and between the most impassable floating mats we meet moreover Nuphar luteum and Utricularia vulgaris. When the mat reaches a very high degree of solidity, and when, therefore, it becomes difficult to recognize it as a floating one, Typha is replaced as dominant species by Phragmites communis or by Glyceria maxima, but this change in facies is not accompanied by a change in the floristic composition. The changes in a transect through a floating mat which at one end was almost impassable and at the other end rather solid, are recognizable in the records 10 to 12 (table 1 ).

On the floating mats some characteristic species of the ScirpetoPhragmitetum (viz. Sparganium erectum ssp. polyedrum, Acorus calamus and Sagittaria sagittifolia) are lacking, and this applies also to some of the characteristic species of the Cicuteto-Caricetum pseudocyperus Boer 1942 (viz. Cicuta virosa, Carex pseudocyperus and Calla palustris), an association which in its floristic composition shows a strong resemblance to the Scirpeto-Phragmitetum. VAN DonselaAR 1961 quotes as species which differentiate the Cicuteto-Caricetum pseudocyperus from the Scirpeto- 
Phragmitetum, Stachys palustris, Myosotis scorpioides, Galium palustre, Lysimachia vulgaris, Lycopus europaeus and Solanum dulcamara, all of them species that are met with on the floating mats of this "Kil". It are species occurring in water that is less deep than that in which the Scirpeto-Phragmitetum is normally found.

Notwithstanding the presence of the above-mentioned differential species of the Cicuteto-Caricetum pseudocyperus, the aspect of the floatingmat vegetation is typically that of a Scirpeto-Phragmitetum. The similarity with the latter is so strong that we often did not perceive that we were dealing with a floating mat before we had set foot on it. The aspect of the Cicuteto-Caricetum pseudocyperus, on the other hand, is entirely different, as it is largely determined by the presence of herbs of lower stature.

The way in which the floating mats in the "Kil" develop, is also entirely different from that in which the floating mats belonging to the Cicuteto-Caricetum pseudocyperus are formed. According to the literature (Boer 1942, VAN Zinderen BAKKER 1942), the latter develop out of a Stratiotes vegetation in which Cicuta virosa becomes established. The latter develops a floating root-system of great extension, and by this the foundation is laid for a floating mat which forms a suitable substrate for the establishment of various other species. The two Typha species are at first absent, but they may make their appearance at a later stage in the development of this type of floating-mat vegetation. In the "Kil" at Hurwenen, on the other hand, the development of the floating mat begins with the establishment of these two species, especially with that of Typha angustifolia. In the section dealing with the "Mode of rooting" the way in which in this case the floating mat starts its development, will be described in some detail.

The floating mats in the "Kil" of Hurwenen agree in structure with the "primary floating mats" mentioned by Schierbeer (1917). VAN Zinderen BAKKer (1942) changed the name introduced by ScHierbeEK into that of "attached floating mats". On account of their structure and mode of development the vegetation of the floating mats in the "Kil" of Hurwenen are included in the Scirpeto-Phragmitetum.

\subsection{Caricetum gracilis-vesicariae}

In passing from the zone which is the habitat of the ScirpetoPhragmitetum, to that with a water depth of less than $30 \mathrm{~cm}$., which for the greater part is occupied by the Caricetum gracilis-vesicariae Westhoff 1949, one hardly notices a change. As Phragmites remains the dominant species, the vegetation looks at first sight like a homogeneous mass of reed. Closer inspection, however, reveals that some new accompanying species have arrived, and that some others have disappeared. The most important addition is that of Carex acuta (record 13), which always reaches a fair degree of covering; occasionally the area covered by it is even larger than that covered by Phragmites. Other new arrivals are Carex vesicaria, Phalaris arundinacea, Lysimachia vulgaris, Lythrum salicaria and Calamagrostis canescens. At the same time 
the following species disappear, viz. Alisma plantago-aquatica, Typha angustifolia, Typha latifolia, Sparganium erectum ssp. polyedrum and Ranunculus lingua.

In those places where in the course of the year the soil rises from time to time above the surface of the water, Phragmites disappears, whereas the floristic composition of the vegetation undergoes no further change (record 14). As the boundary line between the zone with Phragmites and that without Phragmites coincides with that of the area which is mown or grazed, it looks probable that the disappearance of Phragmites is partly due to activities of this kind (Bitrmann, 1953).

Besides the vegetations that have been discussed here, some other ones are found in the "Kil" of Hurwenen, e.g. a vegetation with Carex disticha as dominant species, a plantation of willows, and vegetations belonging to the Valerianeto-Filipenduletum Westhoff 1949. They are dealt with in the paper by VAN DonselaAR (1961); from the point of view of this investigation they are of no importance.

3. FACTORS RESPONSIBLE FOR THE DIFFERENTIATION OF THE VEGETATION

\section{1. ABIotic Factors}

\section{1. 1. Light}

As no measurements of the light intensity were made, we will confine ourselves to a few general remarks.

In our discussion of the Potamion we have already drawn attention to the fact that in those places where the floating leaves form a closed covering, no submersed hydrophytes are present. It seems plausible to assume that their absence is due to lack of light.

In reed fields where the leaves form a closed canopy, remarkably few other plants are met with. Here too the light intensity will probably play the part of a limiting factor.

Where in the zone in which water is changing into land a Willow or an Alder make their appearance, the original vegetation is seen to disappear below these shrubs. Underneath a shrub of Salix cinerea in the otherwise closed vegetation on a floating mat open water was found.

\section{1.2. Wind}

Floating hydrophytes may be carried away by the wind. The dike on the south and west side of the "Kil" at Hurwenen offers apparently insufficient protection against the latter, for in the open water and between the floating leaves of the rooting hydrophytes floating Lemna species and Hydrocharis are completely absent. However, they at once make their appearance where along the bank the force of the wind is broken by plants rising above the surface of the water.

When the floating leaves of $\mathcal{N} u p h a r$ and $\mathcal{N} y$ mphaea are exposed to a strong wind, they may be overturned with the result that they assume 
a more or less vertical position. This, however, does not seem to cause them any harm. In shallow spots and also in the marginal vegetation where there is not enough space for them, these leaves rise in a similar position above the surface of the water, but $\mathcal{N y m p h a e a}$ plants with such leaves nevertheless flower normally.

Not represented in the "Kil" is the community which is characteristic for windstill spots, viz. the Hydrochareto-Stratiotetum. Such windstill spots are, however, not entirely lacking.

In the marginal zone, where the vegetation consists for the greater part of species whose slender stems and leaves rise high above the surface of the water, these parts of the plant show a high degree of flexibility, and are in this way adapted to a habitat which on the side of the open water is fully exposed to the wind. The stems of Scirpus lacustris, for instance, are so flexible that they can be bent in the form of a half circle without breaking.

\section{1.3. Depth of water}

The marginal vegetation of an open water shows a distinct zonation corresponding to changes in the water depth. Therefore, in a study of the factors that are responsible for the differentiation of the vegetation, one of the first things that we have to know, is in what way the species are distributed over the various depths.

If in a definite former river bed the change of one vegetation type into another would depend entirely upon the depth of the water, it ought to be possible to recognize the various types of vegetation from a table in which the species are arranged according to the range of depths at which they occur. For the "Kil" of Hurwenen these data are given in Table 2.

The measurements on which this table is based, were made in a single summer; in the course of the latter the water level did not change very markedly. However, as the figures were obtained in a single summer and in one locality, they have a relative value only.

Apart from the range of depths in which a species occurs, the range of depths in which it is dominant, was recorded; the latter is indicated in the table by a thickening of the line which shows its presence.

The combination of letters in the first column behind the names of the species indicates the name of the vegetation unit for which the latter may be regarded as a characteristic species.

The range of depths in which the individuals rooting in a floating mat are found, is indicated separately, as the floating mat is to be regarded as a different habitat.

The species occurring in a similar range of depths are arranged in groups.

Group 1 comprises species which occur mostly in deep water, i.e. in depths varying between 250 and $50 \mathrm{~cm}$. To this group belong $\mathcal{N}$ ymphaea alba, $\mathcal{N}$ ymphoides peltata, Nuphar luteum and Utricularia vulgaris. It are all characteristic species of the Potamion.

Group 2 contains the floating species. The latter are found in water of which the depth varies from 100 to $0 \mathrm{~cm}$. It are Hydrocharis morsus- 
TABLE II

Depth range at which the various species occur.

\begin{tabular}{|c|c|c|c|c|c|c|c|c|c|c|c|c|c|c|c|}
\hline & & \begin{tabular}{|l|l|}
244 & 224 \\
225 & 205 \\
\end{tabular} & \begin{tabular}{|l|l|}
2045 & 184 \\
105 & 165 \\
\end{tabular} & \begin{tabular}{l|l|l}
4 & 154 & 144 \\
5 & 145 & 125 \\
\end{tabular} & 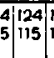 & \begin{tabular}{ll|l}
114 \\
105 & 9 \\
\end{tabular} & \begin{tabular}{|l|l|}
104 & 94 \\
95 & 85 \\
\end{tabular} & 75 & \begin{tabular}{l|l}
74 & 5 \\
65 & 5 \\
\end{tabular} & & \begin{tabular}{l|l|}
54 & 44 \\
45 & 35
\end{tabular} & \begin{tabular}{|l|l}
34 & 2 \\
25 & 1
\end{tabular} & \begin{tabular}{l|l}
24 & 1 \\
15 &
\end{tabular} & \begin{tabular}{|l|l|}
14 & 4 \\
5 & 0 \\
\end{tabular} & + \\
\hline i. Nymphaed albe & $\boldsymbol{\rho}$ & & & & & & & & & & & & & & \\
\hline Nymphoides peltats & $\overline{\boldsymbol{P}}$ & & & & & & & & & & & & & & \\
\hline Nuphar Iuteum & $\boldsymbol{\rho}$ & & & & & & & & & & $\Xi$ & $=$ & & & \\
\hline Utricularia vulgaris & $\boldsymbol{P}$ & & ב & & & & & & & & $=$ & & & & \\
\hline 2. Hydrocharis monsus-ranae & $\boldsymbol{\rho}$ & & & & & & & & & & $\approx$ & & & & \\
\hline Lemna trisulce & $\boldsymbol{\rho}$ & & & & & & & & & & & $E$ & & & \\
\hline Lemneminor & $\boldsymbol{\rho}$ & & & & & & & & & & $=$ & in & & & \\
\hline Spirodela polymhiza & $\rho$ & & & & & & & & & & N & \pm & \pm & & \\
\hline 3.5cirpus lacustris & Phon & & & & & & & & & & & & & & \\
\hline Sparganium erectum & Phon $S$ & & & & & & & & & & $=$ & & & & \\
\hline Typhe angustifolia & Phan & & & & & & & & & & & & & & \\
\hline Typha latifolia & Phon 5 & & & & & & & & & & $=$ & E- & & & \\
\hline Alisma plantago-squatica & Phia & & & & & & & & & & $\Longrightarrow$ & $=$ & & & \\
\hline 4. Butomus umbellatus & Phon & & & & & & & & & & & E & & & \\
\hline Ranunculus lingue & Phon & & & & & & & & & & & & & & \\
\hline Carex riparia & $M$ & & & & & & & & & & & 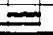 & & & \\
\hline 5 Phregmites communis & Phis & & & & & & & & & & $\equiv$ & $\equiv$ & & & \\
\hline Mentha oquatica & $\ldots$ & & & & & & & & & & 工 & 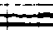 & & 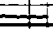 & \\
\hline Equisetum fluviatile & $\ldots$ & & & & & & & & & & & مin & 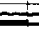 & $\Rightarrow$ & \\
\hline Rumex hyotrolapathum & Phia & & & & & & & & & & & $\underline{E}$ & 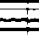 & 幽 & \\
\hline Rorippa amphibia & Phia & & & & & & & $=$ & & & $\Longrightarrow$ & \pm & $=$ & 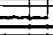 & \\
\hline 6. Sium latifolium & Phia & & & & & & & & & & & & & 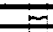 & \\
\hline Glyceria maximo & Phis & & & & & & & & & & & & & & \\
\hline Myosotis scampioides & $=-$ & & & & & & & & & & $=$ & \pm & & & \\
\hline Iris pseudecorus & --- & & & & & & & & & & & + & $=$ & & \\
\hline Solanum dulcamant & $\boldsymbol{R}$ & & & & & & & & & & & & & & \\
\hline Stochys polustris & $\boldsymbol{P}$ & & & & & & & & & & & & & & \\
\hline Polygonum omphibium faternestre & --- & & & & & & & & & & & $E$ & $\underline{\underline{z}}$ & $\Rightarrow$ & \\
\hline Corex ecuto & $M C$ & & & & & & & & & & & & & & \\
\hline Canox vesicario & $M \bar{C}$ & & & & & & & & & & & 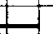 & & $=$ & \\
\hline Lythrum salicarie & --- & & & & & & & & & & C. & $E$ & & $=$ & \\
\hline Galium polustre & $M$ & & & & & & & & & & = & $\neq$ & & $\underline{1}$ & \\
\hline Phalaris arundinaced & Phis & & & & & & & & & & Z & E & & & \\
\hline 7. Lysimachia vulgaris & $\boldsymbol{R}$ & & & & & & & & & & & & $=$ & & \\
\hline Epilobium hirsutum & $R$ & & & & & & & & & & & $E$ & $\simeq$ & & \\
\hline Senecio Aeludosus & $\ldots$ & & & & & & & & & & & & & & \\
\hline Salix spece. & $\boldsymbol{R}$ & & & & & & & & & & & E & & & \\
\hline Calamagnostis asnescens & $\boldsymbol{R}$ & & & & & & & & & & - & & & & \\
\hline e.Equisetum palustro & $\boldsymbol{R}$ & & & & & & & & & & & & & & \\
\hline Carex disticha & $R$ & & & & & & & & & & & & & & \\
\hline 9 valemiana officinalis & $\boldsymbol{R}$ & & & & & & & & & & & & & & \\
\hline Iacarex psewdocyporus & Phon & & & & & & & & & & E & - & & & \\
\hline sium erectum & Phid & & & & & & & & & & 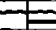 & \pm & 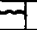 & & \\
\hline Lycopus eunopaeus & & & & & & & & & & & & $=$ & & & \\
\hline
\end{tabular}

The first column behind the names of the species gives the names of the vegetation unit in which the latter occur as characteristic species; $P=$ Potamion eurosibiricum; Phon $=$ Phragmition eurosibiricum; Phon $\mathbf{S}=$ Scirpeto.Phragmitetum medioeuropaeum; Phia $=$ Phragmitetalia eurosiberica; $\mathbf{M}=$ Magnocaricion elatae; $\mathbf{M} \mathbf{C}=$ Caricetum gracilis-vesicariae. $\mathbf{R}$ means that the species belongs either to a community which in the succession comes after the Magnocaricion, or else to one which owes its origin to human interference. When no letter or letter combination is added, there is no community for which the species can be regarded as characteristic.

straight line: rooting in the bottom of the pool. undulating line: rooting on a floating mat.

In the heavier part of the line the species may be dominant. 
ranae, Lemna trisulca, L. minor and Spirodela polyrhiza. These plants too are characteristic species of the Potamion.

Group 3 comprises rooting species which are confined to depths varying between 100 and $5 \mathrm{~cm}$. It are Scirpus lacustris, Sparganium erectum, Typha angustifolia, T. latifolia and Alisma plantago-aquatica. The first four are characteristic species of the Phragmition, the last-mentioned one is a characteristic species of the Phragmitetalia.

In group 4 are brought together species which are also confined to submersed soils, but which do not occur in depths of more than $50 \mathrm{~cm}$. It are Butomus umbellatus, Ranunculus lingua and Carex riparia. The first two are characteristic species of the Phragmition, whereas Carex riparia is a characteristic species of the Magnocaricion.

Group 5 comprises species which are already present in deep water $(80 \mathrm{~cm}$.), but which occur also on soils in which the water table is found below the surface. To this group belong Phragmites communis, Mentha aquatica, Equisetum fluviatile, Rumex hydrolapathum and Rorippa amphibia. Mentha aquatica and Equisetum fluviatile do not indicate definite communities, but the three other ones are characteristic species of the Phragmitetalia.

The species of group 6 behave in a similar way as those of group 5, but they are confined to depths of $50 \mathrm{~cm}$. and less. Of the twelve species referred to this group three are characteristic species of the Phragmitetalia, viz. Sium latifolium, Glyceria maxima and Phalaris arundinacea, and three of the Magnocaricion, viz. Carex acuta, C. vesicaria and Galium palustre, whereas two,viz. Solanum dulcamara and Stachys palustris belong to vegetation units which in the succession come after units of the Magnocaricion or to units which owe their origin to human interference.

The species of group 7 differ from those of the two preceding groups because they do not occur in water with a depth of more than $35 \mathrm{~cm}$. It are Lysimachia vulgaris, Epilobium hirsutum, Senecio paludosus, Salix spec. and Calamagrostis canescens. No characteristic species of the Phragmitetalia are met within this group. With the exception of Senecio paludosus they belong to similar vegetation units as the two lastmentioned species of group 6 .

Group 8 comprises species which are occasionally found in shallow water, but which, as a rule, grow on soil in which the water table lies below the surface. To this group belong e.g. Symphytum officinale, Eleocharis palustris, Agrostis stolonifera and Poa trivialis. None of them are characteristic species of the Phragmitetalia. By way of example Equisetum palustre and Carex disticha are included in the table.

In group 9 species are brought together which are even less often met with in shallow water than those of group 8, so e.g. Rubus caesius, Thalictrum flavum and Filipendula ulmaria. By way of example Valeriana officinalis is included in the table.

Group 10 comprises a few species which here are found mainly or even exclusively on floating mats. It are Carex pseudocyperus, Sium erectum and Lycopus europaeus.

The way in which the characteristic species of the various vegetation 
units are distributed over the different groups, shows that there exists to some extent a correlation between these vegetation units and definite depth zones. It appears 1) that in water with a depth of 245 to $105 \mathrm{~cm}$. only species are found which belong to the Potamion; 2) that the species which in water with a depth of 105 to $55 \mathrm{~cm}$. occur, are found in this combination only in one association, viz. in the Scirpeto-Phragmitetum; 3) that within the depth zone the pioneer facies are found in the subzone which comprises depths from 105 to $75 \mathrm{~cm}$; 4) that in water with a depth of less than $55 \mathrm{~cm}$. the species of the Potamion are absent, but that the vegetation by which the latter is replaced, does not show a homogeneous structure but is to be referred to two or more distinct communities; 5) that when the depth is less than $25 \mathrm{~cm}$., the characteristic species of the Phragmition have disappeared, and that species belonging to other alliances make their appearance.

We arrive therefore at the conclusion that the transition from the Potamion to the Scirpeto-Phragmitetum, and within the latter, the transition from the various pioneer facies to a more fully developed vegetation are determined by a decrease in depth of the water in which these vegetations occur, but that the transition from the Scirpeto-Phragmitetum to the Caricetum gracilis-vesicariae can not merely be due to a decrease in depth, and that other factors must be involved also when the Caricetum gracilis-vesicariae is replaced by other vegetations, although on the whole it is true that the latter are adapted to drier habitats.

With regard to the species that are rooting in floating mats, it is worth mentioning that a certain number of them (group 10) show in the "Kil" a preference for this particular habitat, and that some other species, viz. Scirpus lacustris, Sparganium erectum and the two Typha species are able to thrive here in shallower water than when they are rooting in the soil of the riverbed itself.

\section{1.4. Consistence of the soil}

Everywhere in the "Kil" the soil consists of clay alternating with layers of sand. However, the uppermost layer consists in every instance of clay, and although the thickness of this layer varies, it is always so thick that the roots do not reach the uppermost layer of sand.

On account of the degree of consistence we distinguish l) incohesive mud; this is a watery mixture of clay particles and plant remains suspended in the lower region of the water; when samples are taken by the aid of a Dachnovsky auger, its presence is perceptible by a slight resistance, but it can not be collected with the auger;2) cohesive mud; black, humus containing clay, less fluid than 1), and offering more resistance to the auger; samples may be taken by means of such an instrument, although it often happens that the mass runs away at the last moment; 3 ) humus containing clay; fairly rigid and mixed with plant remains; can be sampled by means of the auger; 4) ordinary clay, a rigid, compact clay, easily sampled by the auger.

The vegetations belonging to the Potamion, and the various facies 
belonging to the Scirpeto-Phragmitetum appear to be rooting in a soft soil consisting of one of the two kinds of mud. All other vegetations, i.e. those occurring in less deep water, are rooting in a more rigid soil of the kind 3) or 4). It is true that on top of the clay a layer of mud may be present, but the latter is always very thin. Reed stands, other than those belonging to the pioneer facies of the Scirpeto-Phragmitetum, may be rooting in a soft soil as well as in a rigid one, which is in agreement with the fact that they may belong to the Scirpeto-Phragmitetum as well as to the Caricetum gracilis-vesicariae. Stands of Glyceria maxima, however, are apparently always rooting in a thick layer of incohesive mud, although they too may belong to both these associations (see further the section on the mode of rooting).

\subsubsection{Chemical and physical properties of the water}

The chemical composition of the water was not determined. As the area in which the "Kil" is situated, is every winter overflown by the river Waal, the "Kil" will receive every year a copious supply of eutrophic river water. For this reason it is to be expected that the chemical composition of its water will not deviate very strongly from that of the river. In the course of the year small changes may, of course, be effected by the activity of the vegetation, but it did not look probable to us that these changes would be of sufficient importance to cause a differentiation of the latter. We confined ourselves therefore to a study of the $\mathrm{P}_{\mathrm{H}}$ and of the $\mathrm{O}_{2}$-content.

\subsubsection{The $\mathrm{P}_{\mathrm{B}}$ of the water}

As it is known that the $\mathbf{P}_{\mathbf{H}}$ may rapidly change under the influence of the vegetation, it was determined in each of the various communities. The estimations were made by means of Merck's $P_{H}$-paper.

It appeared that the $P_{H}$ varied between 7.2 and 7.5 , but that there was no correlation between the type of vegetation and the $P_{H}$ of the water in which it occurred.

\section{1.5.2. The $\mathrm{O}_{2}$-content of the water}

As the $\mathrm{O}_{2}$-concentration in stagnant water is strongly influenced by plant growth, it was decided to determine its value in the various vegetations that are found in the "Kil". The estimations were made by the aid of the method of WinkLER (15).

The $\mathrm{O}_{2}$ concentration appeared to decrease in the direction of the bottom and also in that of the open water in the centre to that of the densely grown marginal zone. The following figures may give some idea of these changes.

\begin{tabular}{|c|c|c|}
\hline $\begin{array}{l}\text { nvironment: } \\
\text { vater in equilibrium with the air } \\
\text { pen water, } 60 \mathrm{~cm} \text { below the surface } \\
\text { otamion, near the bottom } \\
\text { narginal vegetation, on the border of the Potamio } \\
\text { ame, completely enclosed } \\
\text { elow a floating mat }\end{array}$ & $\begin{array}{l}\mathrm{cc} / 1 \\
6.40 \\
2.85 \\
1.95 \\
1.50 \\
0.00 \\
0.00\end{array}$ & $\begin{array}{l}\text { temperature } \\
20^{\circ} \\
21^{\circ} \\
21^{\circ} \\
21^{\circ} \\
21^{\circ} \\
21^{\circ}\end{array}$ \\
\hline
\end{tabular}


The dominant species are growing in water without $\mathrm{O}_{2}$ as well as in water with a slight amount of $\mathrm{O}_{2}$. It is to be noted that in most of the species ocurring in this environment the shoots and roots are provided with air passages.

\section{2. Biotic FACTORS}

\section{2. 1. Mode of rooting}

As the mode of rooting is not only of importance from a morphological point of view, but may also be regarded as one of the ways in which the various plant species are adapted to their environment, a study of this aspect of plant life may give us perhaps some insight in the way in which the differentiation of the vegetation types is brought about. For this reason the root system of a large number of species was studied. Of the drawings that were made in connection with this study, a few are reproduced here; the other ones have been deposited in the collection of the "Institute for Systematic Botany" of the State University at Utrecht.

The root system of $\mathcal{N} y m p h a e a$ alba, Nymphoides peltata and Nuphar luteum could not be investigated, as the water in which these plants occur is so deep that it was impossible to us to reach their roots. To this end a special apparatus would be required, but such an apparatus was not available to us. In probing the bottom by the aid of an oar, one often strikes a network of rhizomes; the latter can be so dense that it costs some effort to find a place where the oar can be pushed through it.

Scirpus lacustris ssp. lacustris (Fig. 3) develops strong rhizomes consisting of short internodes. The adventitious roots, which reach a length of $20 \mathrm{~cm}$., are spread over the whole surface of the rhizome. The latter undergoes ramification, and at several places a new stem is produced. The ramified rhizomes with the densely packed stems form a strong network with narrow meshes. Ordinarily the rhizomes are found where the non-cohesive layer of mud passes into the cohesive layer or into clay, but this species is also regularly met with on floating mats, although it does not form them itself. As it is firmly anchored by means of the dense network of rhizomes and by the large number of roots, it is not easily uprooted by the wind or by the waves.

The rhizomes of Typha angustifolia (Fig. 4) reach a length of $50 \mathrm{~cm}$., and consist of 2 to $5 \mathrm{~cm}$. long internodes; they are flexible, and contain a large number of air chambers; at considerable intervals they give rise to stems. At the base of each stem we find a large number of long roots, and here one or more new rhizomes develop. Occasionally between the living stems some dead ones may be present.

The rhizomes of Typha angustifolia are found in the layer of noncohesive mud, usually in a horizontal position, but occasionally slightly ascending. The plant is but weakly anchored in the soil, and uprooted rhizomes are not rarely seen floating on the water. They may also become heaped up in the form of a dam along the margin of the pioneer vegetations which surround the open water, 


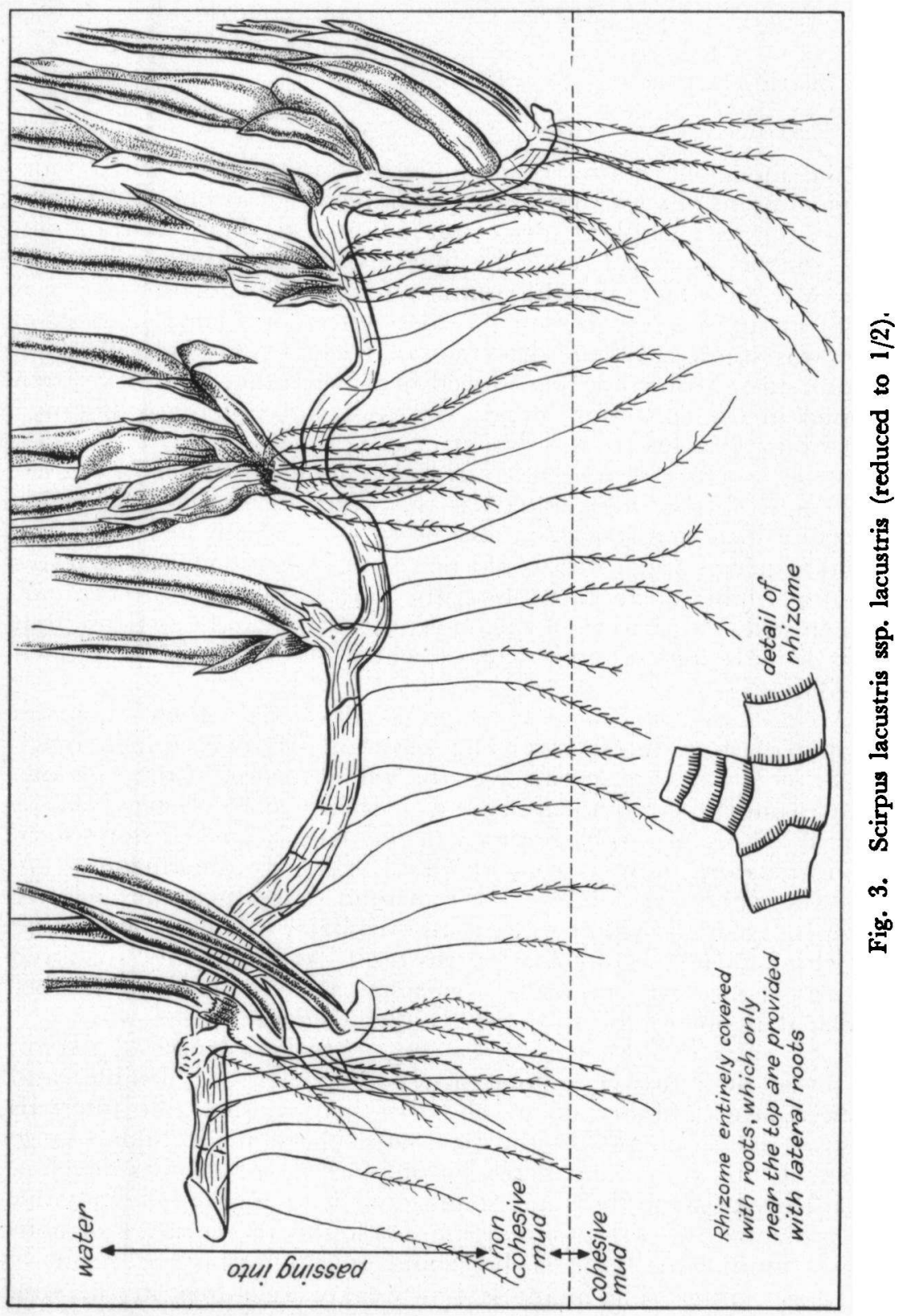




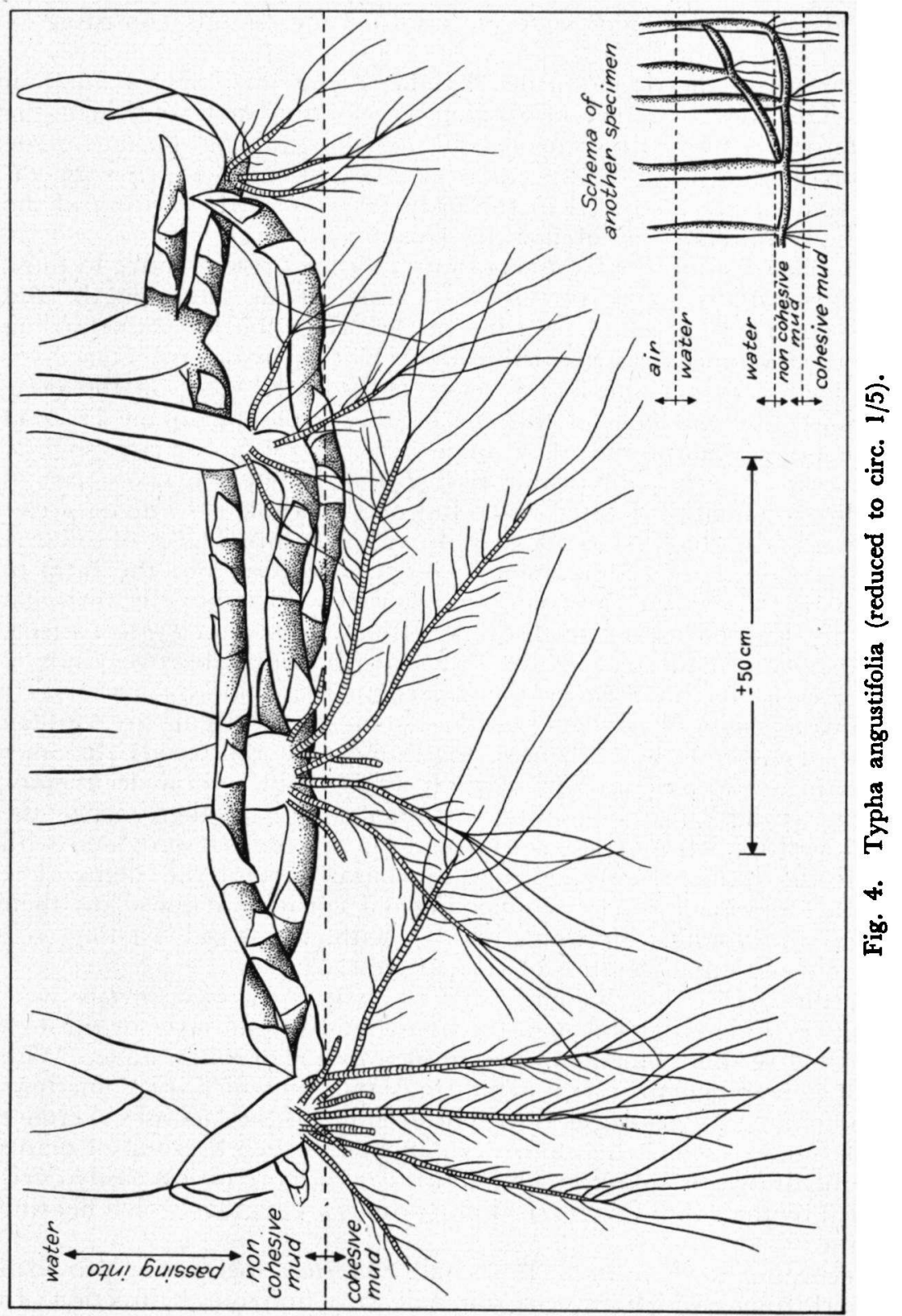


and on such a dam not only new Typha stems arise, but here also plants from shallower water may establish themselves. In spring a drift line formed by a large number of $T y p h a$ rhizomes girdles the dike. In times of flood we even saw floating islands consisting of dead Typha plants.

Apart from the dams formed by the Typha rhizomes, we find in the "Kil" at Hurwenen also extensive floating mats of which the foundation is formed by rhizomes of Typha angustifolia. Borings made it probable that these floating mats have arisen out of a Typha vegetation which were anchored in the ordinary way in the bottom of the riverbed, and not out of floating rhizomes.

The rhizomes of $\mathcal{T}$ ypha latifolia show a striking resemblance to those of $T$. angustifolia. 'They are just as flexible, of the same length, and consist of a similar number of internodes. Here too the stems arising from the rhizomes are separated from each other by several internodes, and dead ones may be found between the living ones on the same rhizome. The rhizomes of this species too are found in the layer of non-cohesive mud, and they may run horizontal or are slightly ascending. It is not impossible that Typha latifolia too takes part in the development of floating mats, but on the whole it seems to prefer floating mats which have reached already a certain degree of solidity. In that case it is accompanied by Glyceria maxima, but the ratio in which the two species are represented, varies. Whether the rhizomes that are washed ashore on the dike belong partly to Typha latifolia, could not be made out, as the difference between the two kinds of rhizomes is too small to be recognized in the field.

In Sparganium erectum ssp. polyedrum some of the stems are swollen at the base. From these corms spring thin, tough and woody rhizomes consisting of internodes which reach a length of several decimeters. These "strings" bear a number of other stems or other corms; the latter with or without leaves. The internodes are not provided with roots; the latter all spring from the basal part of the stems. The presence of rhizome parts connecting old corms that have lost their leaves, and young leafy stems with or without a basal swelling, is a rather conspicuous feature of this species.

In the "Kil" the rhizomes and roots of Sparganium erectum were found creeping either through the non-cohesive mud layer or through the cohesive mud which can be sampled by means of an auger. With its long creeping rhizomes it can form islands, in which it is sometimes accompanied by Scirpus lacustris. On account of the lack of coherence of the mud in which the plants are anchored, such a group of plants may be drawn in any direction, and it is also more or less easily overturned by the wind. Overturned individuals are regularly seen floating on the water.

According to Warming (1909), all Equisetum species are provided with rhizomes which traverse the soil in a horizontal direction. In the case of Equisetum fluviatile we did not succeed in unearthing these rhizomes. Where the erect stems traverse the incohesive and the cohesive layer of mud, they are at the nodes provided with roots. 
In individuals that were found growing on floating mats, the stems appeared to enter the mat from beneath, which means that these plants must have been present already at the moment the mat was formed; their stems apparently rise from rhizomes that are buried in the mud underneath the mat. The way in which this species is anchored in the soil, may be described as quite firm.

Phragmites communis possesses thick, smooth rhizomes. On the nodes of the latter only few roots are produced. From several of the nodes stems arise, and the buds in the basal part of these stems give rise to other stems. In contrast to the nodes of the rhizome, those of the erect stems bear several roots, and these roots are in their turn provided with several lateral roots. After some time the tip of the rhizome turns upwards, and then the rhizome passes into an ordinary erect stem.

The rhizomes of Phragmites are often found at a considerable depth in the soil. The latter consists, as a rule, of solid clay, eventually covered by a thin layer of vegetable detritus. The rhizomes never penetrate into this layer, but the roots which spring from the basal part of the stem, do.

Phragmites also forms floating mats. In this case the rhizomes produce in combination with the strongly ramified basal part of the stems a rigid texture which serves as a suitable substrate for the development of other plant species. It is not impossible that it are the Phragmites plants that are anchored in the soil of the marginal zone whose rhizomes grow out into the open water, and that this leads to the development of the floating mat.

On account of the density of the network formed by the rhizomes and stems as well as on account of the depth at which the rhizomes are buried in the soil, Phragmites is very firmly anchored.

Glyceria maxima produces stolons which at every node are provided with roots. Finally the tip of the stolon turns upwards, and grows out into an erect stem. Occasionally erect stems are also produced at the nodes of the stolon. The greater part of the roots springs from the basal part of the erect stems. Occasionally the stems do not assume their erect position at once, but grow out in a horizontal direction and remain creeping over a distance of a few decimeters.

Glyceria roots in the mud, which may be cohering enough to be sampled by means of an auger, but it roots also in the solid clay along the margin of the river bed. It occurs in addition on floating mats. The stolons and the erect and creeping stems sometimes form a mat which is strong enough to render a soft mud passable.

Glyceria may be regarded as firmly anchored.

Carex acuta possesses 2 to $3 \mathrm{~cm}$. long rhizomes which at the top pass into erect stems. The rhizomes consist of more than one internode. At the base of the erect stem several roots are produced by which the plant is firmly anchored in the soil.

The roots and rhizomes of Carex acutaa re usually found in a fairly rigid clay, but occasionally they are met with in floating mats; this species, however, does not form floating mats. The shortness of the rhizomes explains the tufted growth of this species. 
The part of the stem of Mentha aquatica (Fig. 5) which is suspended in the water, often occupies a horizontal or ascending position; it may reach a length of $40 \mathrm{~cm}$., and produces new stems at several of the nodes. Roots are produced at the nodes of the part that is suspended in the water as well as in that which is buried in the soil; this buried part may also be absent. It sometimes happens that several individuals form together a floating vegetation which is enclosed by the stems of plants like Scirpus lacustris that are rooting in the bottom of the river bed.

Mentha aquatica therefore may occur as a floating plant, but it may also be rooting in soils of varying consistence.

The stems of Rorippa amphibia are, just like those of Mentha aquatica, partly submersed, and these submersed parts are partly horizontal. However, in contrast to Mentha aquatica it are not only the basal parts that are submersed. In Rorippa amphibia too the submersed part produces ascending branches, and here too in the axil of the leaves a bundle of roots is developed. In contrast to Mentha aquatica this species never grows gregariously; as a rule, it occurs in the form of small groups in the midst of the other accompanying species.

The ascending stems of Ranunculus lingua are often provided with submersed stolons which, just like the submersed part of the main stem, are rooting at the nodes. The stolons are also provided with leaves which rise above the surface of the water. When they are fullgrown, the tip turns upwards, and grows out into another flowering stem. The horizontal part of the stolon creeps through the incohesive or the cohesive layer of mud or, when the plant grows on a floating mat, through the latter.

In Sium latifolium roots are produced only at the base of the stem; these roots in their turn produce lateral roots. The basal part of the stem is sometimes slightly swollen, and in older individuals it is slightly lignified. Sium latifolium may be found rooting in clay as well as in mud, and it occurs also on floating mats.

In Alisma plantago-aquatica the stem arises out of a tuber, which may show various constrictions. The whole surface of this tuber is covered with long and thin roots. Alisma plantago-aquatica roots in the upper layer of clay, in the two layers of mud, and also in floating mats.

In Lysimachia vulgaris the basal part of the stem and the nodes of the stem part that remains below the surface of the water, are provided with roots. The buds on the basal part produce branches which over a distance of about $30 \mathrm{~cm}$. run in a horizontal position, but which then turn upwards and develop into ordinary flowering shoots.

The plants of which the root system was studied, belong partly to the dominant species of the various communities, and partly to the accompanying ones. It now appears that the various dominants are all provided with rhizomes. This correlation suggests that they owe their dominance to the rapid growth of the rhizomes, which enables them to occupy in a short time an area of considerable extent. The network of rhizomes, moreover, becomes so dense that lack of space will soon make the establishment of other species difficult or impossible. 


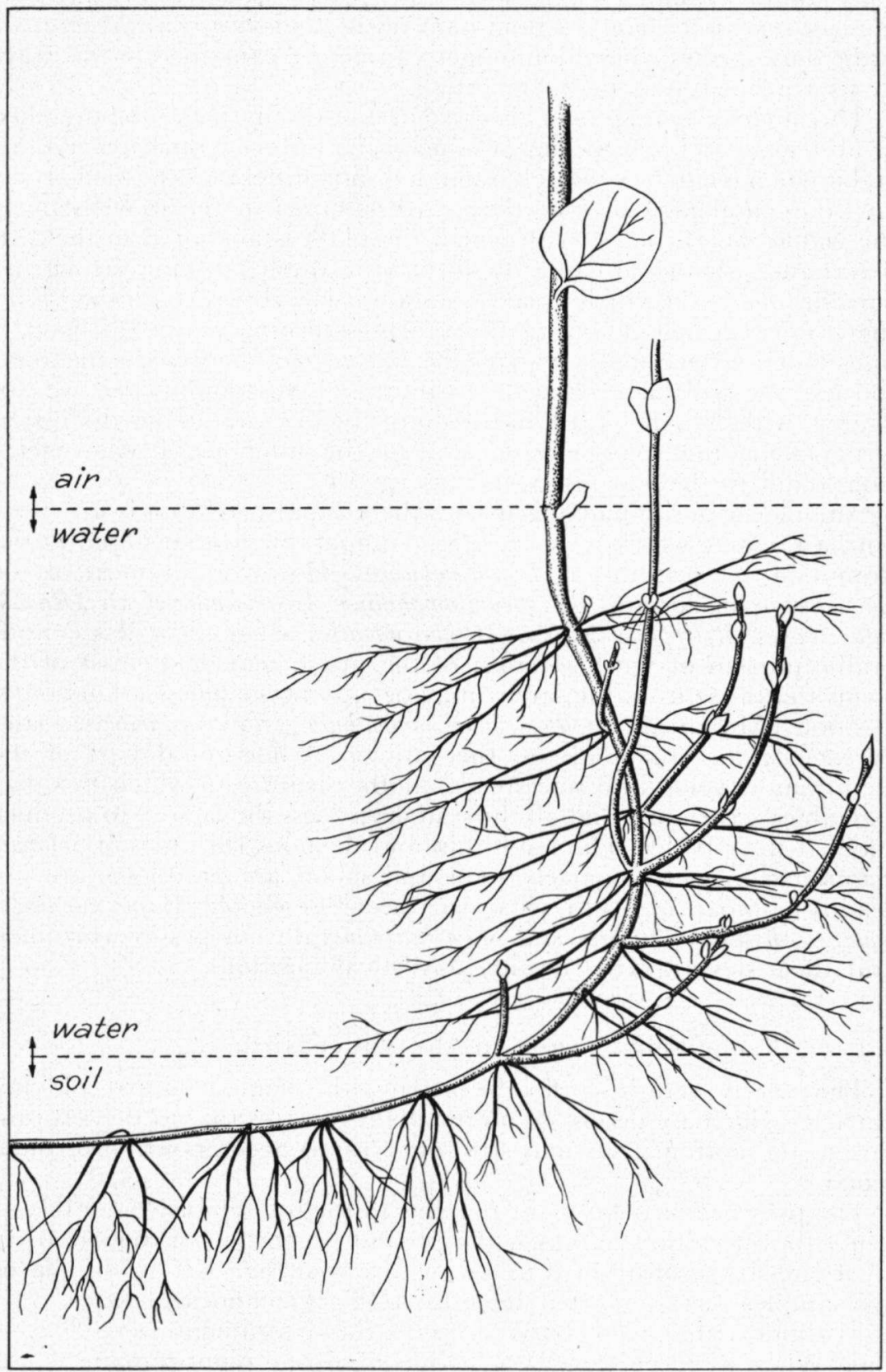

Fig. 5. Mentha aquatica (reduced to $1 / 2$ ). 
This would explain the prevalence of definite facies in the ScirpetoPhragmitetum. Carex acuta, a dominant of the Caricetum gracilis-vesicariae, is the only species whose dominance can not be explained in this way, as its rhizomes remain but short.

The mode of rooting may also give us an explanation of the presence or absence of definite species in some of the former river beds. To this end it will have to be considered in relation to differences in the various environmental factors, especially to differences in the movement of the water. The firmness with which the plant is anchored in the soil, determines whether it can grow in moving water and how strong the current may be in which it can maintain itself. However, in the "Kil" the water movement during the yearly returning period of flood is but small, and does not endanger the existence of the weakly anchored species. We will have occasion to return to this point when we are dealing with the "Kil" at Waardenburg (p. 157) and in our discussion of the factors that may be responsible for the differences in the vegetation found in the various river beds (p. 159).

Among the accompanying species there is only one that is provided with a rhizome which is more or less comparable to that found in the dominant species; this is Iris pseudacorus. However, in most of the accompanying species (Polygonum amphibium, Lysimachia vulgaris, Ranunculus lingua, Rorippa amphibia, Mentha aquatica) a more or less considerable portion of the basal part of the main stem or at least of the stems that arise from the latter, may occupy nevertheless a horizontal position. Moreover, in Polygonum amphibium, Rorippa amphibia and Mentha aquatica the buds on the submersed horizontal part of the stem may develop into side stems, another feature in which this part resembles a rhizome, and all these stems possess the faculty to produce roots at their nodes. The long, thin and flexuous rhizomes of Solanum dulcamara, on which sparsely roots and shoots are produced, are not readily comparable with what we meet elsewhere. Alisma plantagoaquatica, Lythrum salicaria and Sium latifolium do not possess rhizomes, and their stems always occupy a vertical position.

\subsection{Preceding stages in the succession}

The yearly returning floods bring with them a supply of clay particles which are deposited on the plant remains that in the autumn sink to the bottom; this may prevent a rapid decomposition of these remains.

The presence of these plant remains in the soil enables us to reconstruct the succession to which the present vegetation of the site owes its origin. To reconstruct it in various parts of the "Kil" in 65 places soil samples were collected by means of a Dachnovsky auger. The soil cylinders that were obtained with this instrument were $20 \mathrm{~cm}$. long. When by inspection with the naked eye no plant remains could be detected in them, they were discarded; the other ones were taken to the laboratory for further study. In control samples in which no plant remains could be seen with the naked eye, the latter could not be 
detected either by means of the laboratory method of investigation, and the selection carried out in the field, may therefore be regarded as satisfactory.

In the laboratory the plant remains were separated from the clay particles, so far as possible, by means of a cheese sieve. The remains that were isolated in this way, were studied under the microscope. For comparison slides were made of stems, rhizomes and leaves of all the species that at present occur in the former river beds, and in order to facilitate the comparison drawings were made of the sections. The roots were left out of consideration, as the latter may belong to the present generation. In some samples a comparatively large part of the plant remains could not be identified, but in most of them it appeared possible to identify nearly all of them. Unidentifiable remains are recorded as such.

Within the time and with the means we had at our disposal, the amounts by which the various species are represented, could not be determined quantitatively. We confined ourselves to an approximate estimation of the relative frequency with which the various species are represented. These approximate frequencies are expressed in the diagrams by means of the following symbols, viz. $3=$ very abundant, $2=$ abundant, $1=$ present, $x=$ represented by a few fragments only.

The diagrams are constructed in the same way as the diagrams that are given in pollen-analytical investigations. At the top of the diagram the composition of the vegetation that nowadays is found in the spot where the sample was taken, is indicated by the use of the same symbols.

When we assume that the proportion in which the various species are represented at various depths in the soil, is the same as that in which they are represented in the corresponding communities that at present are living in these and similar habitats, then the diagrams of Fig. 6 may be regarded as approximate records of the succession. In that case these diagrams therefore give us some idea of the changes the vegetation underwent in floristic composition as well as in the frequency with which the component species are represented. However, is this assumption justified? Before entering into a discussion of the results, we will have to answer this question.

The composition of the plant remains that are found at a definite spot, may differ from that of the vegetation which was present at that spot at the time the deposit was formed, for two reaosns. In the first place remains belonging to another kind of vegetation may have been transported to this spot, and remains of the autochthonous vegetation may have been washed away, and in the second place the remains of some of the plant species may have decayed more rapidly than those of other species, which would simulate a better representation of the latter in the original vegetation.

A transport of material is certainly not entirely excluded, as the area in which the "Kil" is situated, is flooded during the winter by the river Waal. However, the current during the period of flood seems to be rather weak in this part. During a visit in such a period 
we even saw no current at all. The conformity in floristic composition between the "Kil" and the former river beds inside the main dike may also be regarded as an indication that the current during the periods of flood can not have been a very important factor. To test the validity of this conclusion we studied the composition of the plant remains that in the spring were found at the bottom of the "Kil". They proved to be entirely derived from the autochthonous vegetation, and as the earlier situation was probably not much different from the present one the possibility of a transport of some importance may be left out of consideration.

The possibility that the remains of the various plant species will decay at a different rate, could be tested only by a comparison of the remains that were found in the clay samples. Indications of differences in the rate of decay may be found in an unexpectedly large or in an unexpectedly small representation of definite species in the samples, or else in a regular increase or decrease of the ratio with which a species is represented, with increasing depth. All species of which the remains could be identified, were studied from this point of view. It were $\mathcal{N}$ ymphaea alba, $\mathcal{N}$ uphar luteum and $\mathcal{N}$ ymphoides peltata as indistinguishable members of one group, and of $\mathcal{N}$ ymphoides alone the fruits; further Potamogeton natans, Stratiotes aloides, Scirpus lacustris, Typha spec., Equisetum fluviatile, Phragmites communis, Glyceria maxima, Carex riparia, Carex acuta, Salix spec., Salix cinerea and Alnus glutinosa.

The first thing which strikes us when we inspect the diagrams, is the absence of the accompanying species. However, as they play but a subordinate part in the vegetation, the chance that their remains are preserved in the soil, is apparently but small.

Species that for one reason or another deserve special attention are Equisetum fluviatile, Glyceria maxima and Carex spec.

Equisetum fluviatile has a silicified epidermis, which might enhance its chance of preservation in the soil. Our findings, however, do not support the idea that it is on account of this feature relatively better represented among the remains in the soil than it is in the living vegetation, and this possibility therefore need not be taken into account in considering the diagrams.

Glyceria maxima is found in the living Phragmition stands certainly as often and as abundantly as Equisetum fluviatile, and we might therefore perhaps expect that it would occur as frequently as the latter in the soil samples, but this expectation is not fulfilled; Glyceria maxima proves to be comparatively rare in them, and is never met with as a dominant species. This should be explained in the following way. When Glyceria maxima becomes dominant, the water is already rather shallow, so that the succession in this habitat is nearly at its end. In soil samples collected under water there is therefore but little chance that this species will be present.

Whether the species of Carex are badly preserved or not, is difficult to decide for us, as below vegetations which in the succession follow on vegetations in which these species occur, no sampels were taken. The only thing we can say is that we found these species but rarely 
in the samples, even when the latter were taken beneath living Carex vegetations.

The preceding considerations, therefore, lead to the conclusion that there are no definite indications for assuming that differences in the rate at which the remains decay, will have exercised a marked influence on the floristic composition of the latter.

The method of determining the succession by means of the identification of plant remains found at different depths in the soil, is regularly applied in historical phytogeography, especially in the study of peat deposits. It has, however, hardly ever been used for the reconstruction of the succession in a more recent past, as it was done here. We applied it also to peat that had been formed a comparatively short time ago in a former river bed inside the main dike at Tuil, and found it here too very suitable for the reconstruction of the succession. JENNings and LAMBERT (1951) successfully used the method for studying the succession in recently formed land at broads in England. They could identify the well-preserved plant remains without the aid of a microscope.

After these remarks on the method applied by us, we may now pass on to an analysis of the diagrams, and see what they teach us with regard to the succession to which the various communities that are now found in this habitat, owe their origin.

In the soil samples collected underneath vegetations belonging to the Potamion we only find species belonging to this alliance. Most samples, however, consist here of pure clay or of mud without any recognizable plant remains.

Underneath the pioneer facies of the Scirpeto-Phragmitetum, i.e. underneath vegetations of Scirpus lacustris, Typha angustifolia, Equisetum

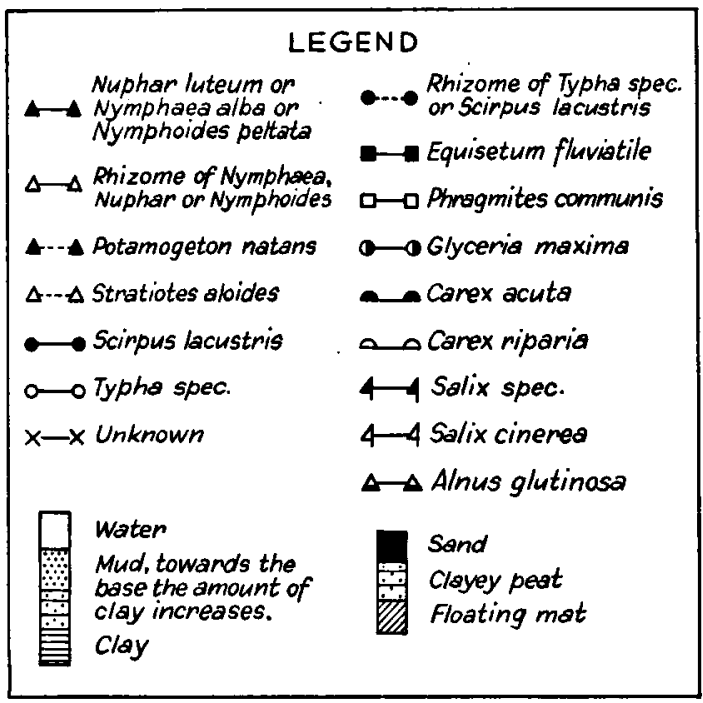

Fig. 6 


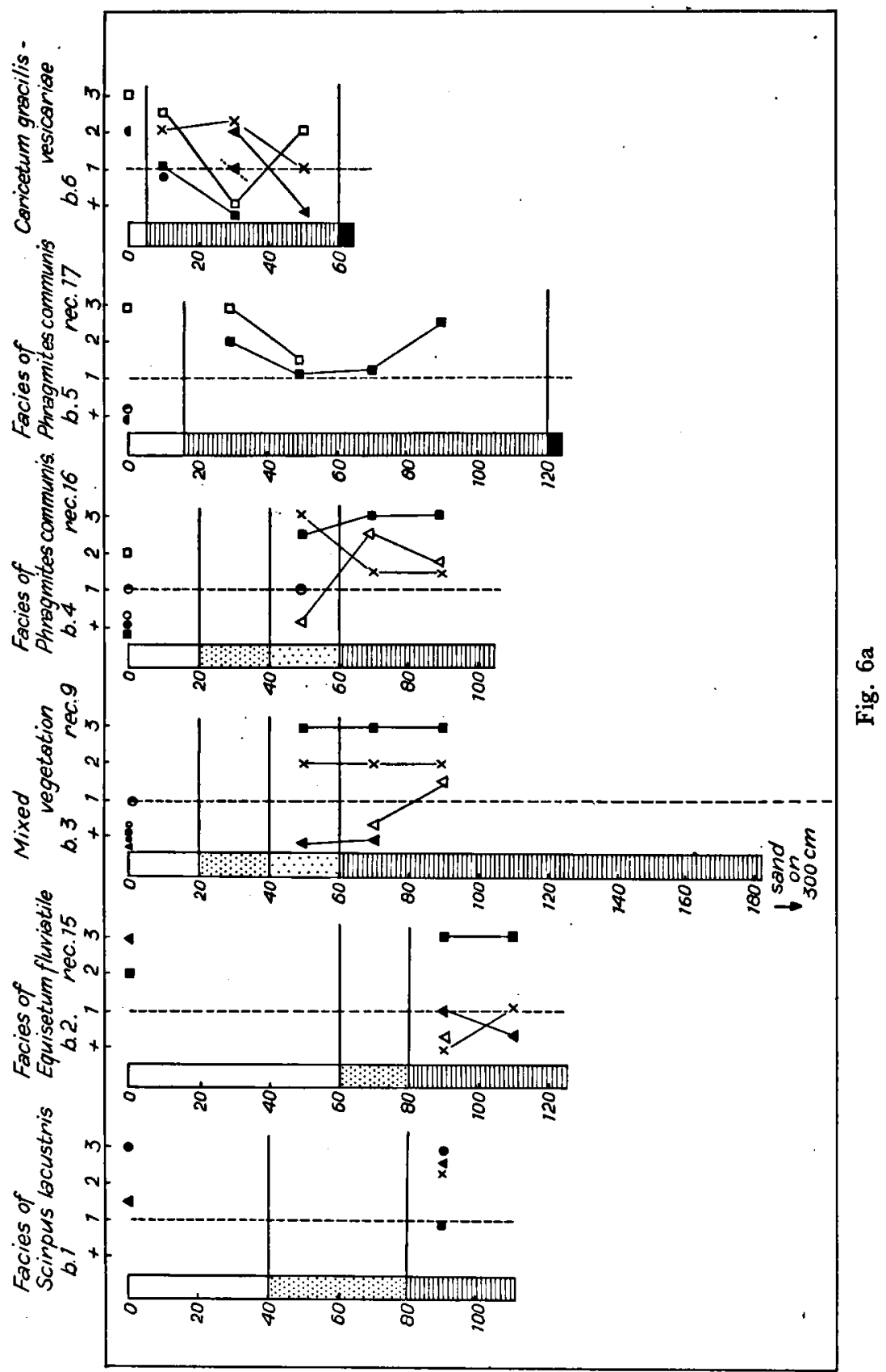




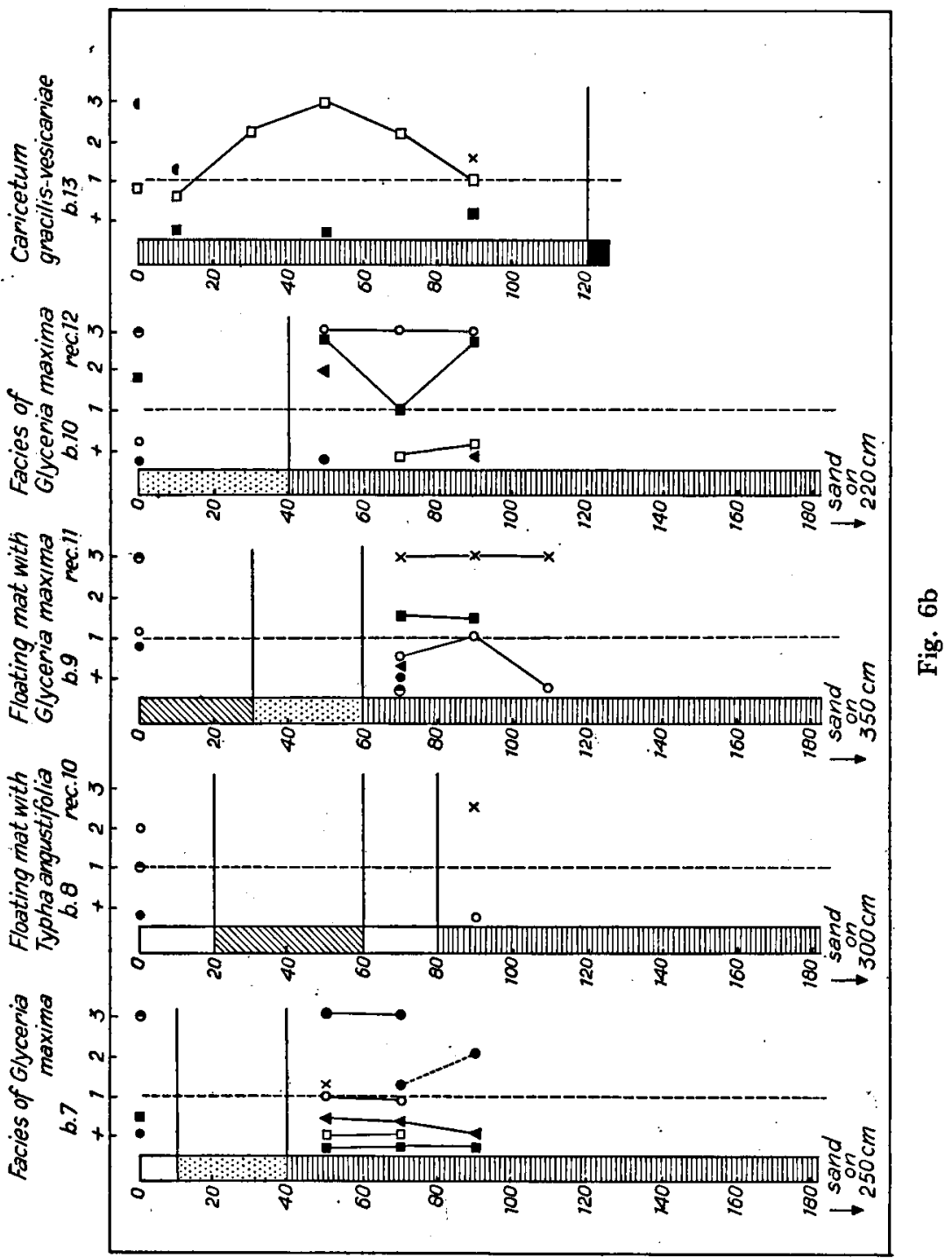




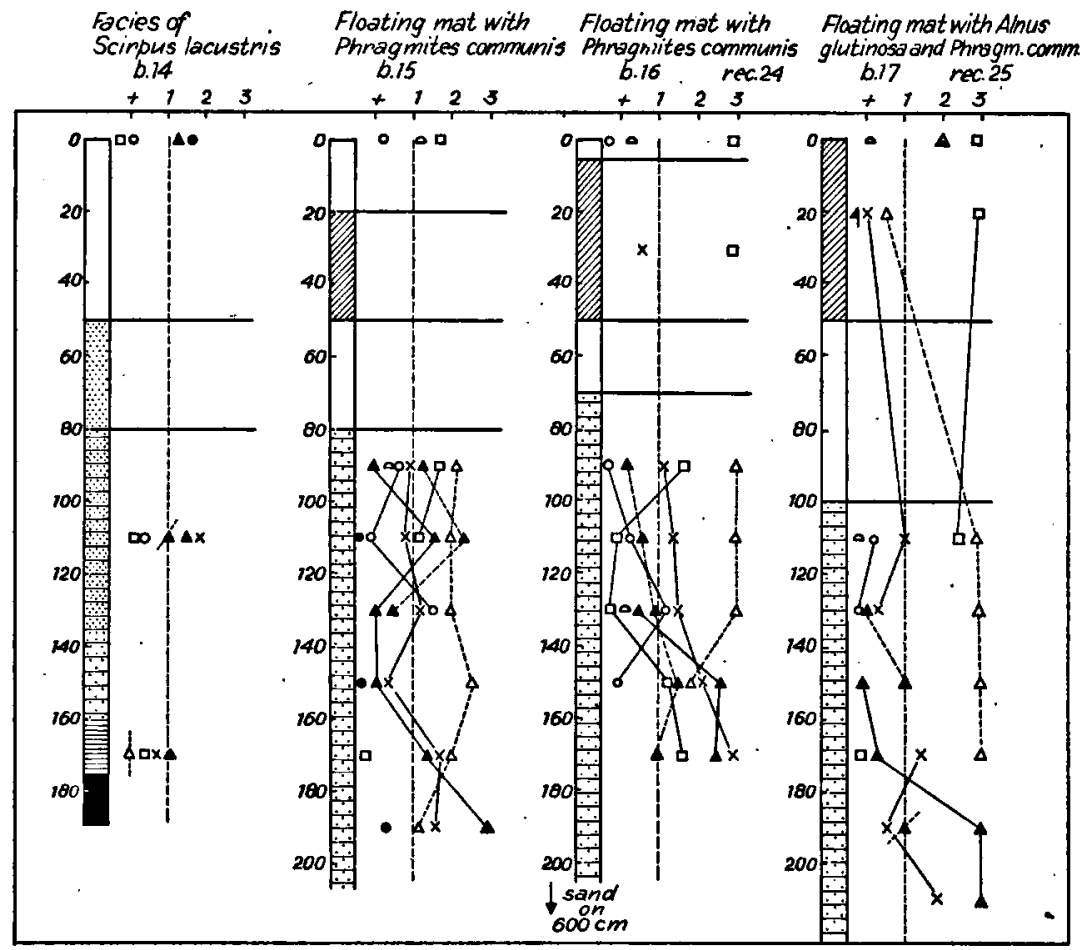

Fig. 6c

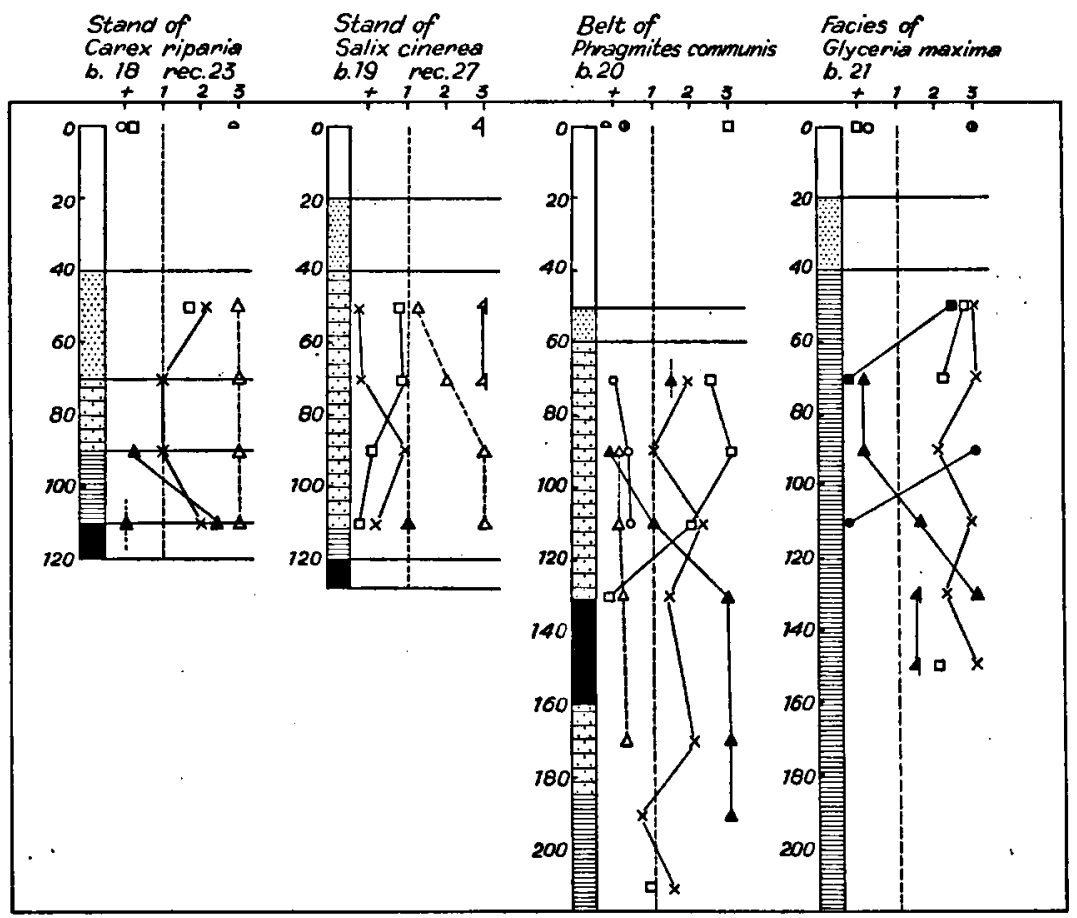

Fig. 6d. Diagrams of soil samples showing plant remains. On top of the diagrams the composition of the present vegetation is indicated by means of the same symbols. 
fuviatile or Phragmites communis, we found a layer of clay containing plant remains which reached a thickness of at the most $40 \mathrm{~cm}$., and which was always covered by a circ. $20 \mathrm{~cm}$. thick layer of plant remains that could not be sampled by means of the auger. The remains that were found in the clay, proved to be derived either from species belonging to the Potamion or from the species of the ScirpetoPhragmitetum which forms the present facies (boring 1 and 2) or from a species from a different pioneer facies of this association.

Boring 3 was made underneath our "mixed vegetation" (record 9, cf. p. 119). It contains rests of a vegetation in which Equisetum fluviatile was dominant as well as rests of plants belonging to the Potamion. This is not unexpected, as at present the "mixed vegetation" is bordered in the direction of the open water by a growth of this Equisetum, and as the latter can live in deeper water than the other species (see the chapter dealing with the mode of rooting). It is to be assumed, therefore, that during the Equisetum stage the bottom underwent a rise which enabled the other species of the "mixed vegetation" to settle here.

In discussing the consistence of the soil in which these types of vegetation are rooting, we have already drawn attention to the fact that stands of Glyceria maxima are always rooting in very soft mud. This layer may reach a thickness of 40 to $50 \mathrm{~cm}$., and can not be sampled by means of the Dachnovsky auger. It was therefore impossible to identify the plant remains in this layer. The latter rests on clay which contains rests of plants belonging to the Potamion and sometimes of one of the pioneer species of the Scirpeto-Phragmitetum (boring 7 and 10), e.g. of Equisetum fuviatile and Scirpus lacustris. Rests of Glyceria maxima itself are hardly ever met with in the clay. It may be that the remains of this species are soon decomposed, but it is also possible that it is unable to settle in a place like this before the layer of mud has reached a certain thickness. It seems to us that a stand of Glyceria maxima, just like our "mixed vegetation", develops only in rather shallow water.

As Glyceria maxima does not occur only as a plant rooting in the soil at the bottom of the "Kil", but is found also on the floating mats, this seems to be a suitable place to discuss the development of the latter.

In discussing the floristic composition of the vegetation that is found on the floating mats, we have already drawn attention to the fact that the thin mats are inhabited by $T_{y p h a}$ angustifolia, but that when the texture of the mat becomes more solid, this species is replaced by Glyceria maxima. This is clearly recognizable in our records 10 and 11, which were made in a transect through a floating mat. The stand of Glyceria maxima growing on the floating mat was seen to pass into a stand of Glyceria rooting in the layer of soft mud in which record 12 was made. In other parts of the "Kil" too one gets the impression that the thin floating mats with Typha angustifolia develop into the more rigid ones inhabited by Glyceria maxima.

In the soil samples collected beneath the floating mat inhabited by Typha angustifolia (boring 8) we find, as a rule, apart from un- 
identifiable rests, remains of species belonging to the Potamion (not present in the given example); in those collected beneath the more rigid mats (boring 9) the remains of species belonging to the Potamion are present too, but besides the latter we note also remains of Equisetum fuviatile and some fragments of Typha. Below the mud in which the Glyceria stand of record 12 (boring 10) was rooting, the remains of Typha and of Equisetum fluviatile are much more abundant. These findings suggest that the development must have proceeded in the following way. Where now a stand of Glyceria maxima is found rooting in the mud at the bottom of the "Kil", formerly a stand of Typha angustifolia must have been present, which was also rooting in the soil at the bottom of the "Kil". During the time the site was occupied by this stand of $\mathcal{T} y p h a$, the bottom of the "Kil" rose here gradually on account of the deposition of plant remains and of clay particles, and when it had risen in this way for some time, it became suitable for the establishment of Glyceria maxima. At the same time along the margin of the Typha stand the rhizomes grew out into the open water, giving rise to the initial stage of a floating mat. The sparse vegetation of Equisetum fluviatile and of species belonging to the Potamion that was present here, was overgrown by this mat. The development that we have sketched here, may be seen in progress in several parts of the "Kil".

Although the part of the floating mat that is nearest to the bank, may be more or less easily passable, it proves impossible to reach the place where it borders upon the open water. Nevertheless, the margin itself of the floating mat may be somewhat more rigid, and may bear plant species like Lythrum salicaria and Epilobium hirsutum that are usually found in "drier" habitats. However, immediately behind this more solid margin, which owes its origin probably to $T y p h a$ rhizomes that have been washed up on the floating mat, the texture of the latter is very loose, and may even be interrupted by open 'spaces in which a Potamion growth is found.

When the floating mat becomes older and the network of rhizomes more dense, it acquires additional solidity by the deposition of plant remains and of clay particles, and then it becomes a suitable site for the establishment of Glyceria maxima, and once established, this species soon begins to determine the aspect of the floating mat. Finally Phragmites communis, approaching from the direction of the bank, begins to invade the floating mat.

In another part of the "Kil" borings were made in a similar transect; they yielded similar results.

The plant remains that are found in the soil beneath a floating mat, show no strict relation with the vegetation of the latter, and are therefore apparently not derived from the vegetation on the floating mat itself; the larger part of the remains of the present vegetation are doubtless retained in the latter itself, and in combination with clay particles precipitated from the water they tend to give greater solidity to the mat.

In the borings underneath a reed stand we notice, as a rule, the 
presence of a layer of sand at a depth of less than $1.5 \mathrm{~m}$. The plant remains in the clay deposit which is found on top of the sand, consist always of rests of Phragmites itself mixed with those of Equisetum fluviatile, and sometimes preceded by rests of species belonging to the Potamion (boring 5). However, we have also found reed stands on a thick layer of clay in which indications are met with of the presence of a vegetation adapted to deeper water (boring 4, rec. 16). This reed stand was found in a transect in which it bordered in the direction of the bank on the denser reed stand (rec. 17) in which boring 5 was made, and in the direction of the open water on the "mixed vegetation" (boring 3, rec. 9). The latter vegetation bordered on the stand of Equisetum fluviatile (rec. 15) in which boring 2 was carried out. The borings prove that Phragmites is extending its area in the direction of the open water, and that it is enabled to do this because the bottom of the river bed is gradually rising (top of the layer of clay in boring 5 $20 \mathrm{~cm}$. below the surface of the water, in boring $460 \mathrm{~cm}$., in boring 3 $60 \mathrm{~cm}$. and in boring $280 \mathrm{~cm}$.; top of the layer of mud in boring $4 \mathrm{en} 3$ 20 to $30 \mathrm{~cm}$. below the surface, in boring $260 \mathrm{~cm}$.). Phragmites behaves therefore in a similar way as Glyceria maxima.

The borings of which the results were discussed in the preceding paragraph, were made in reed stands found halfway between the eastern and the western part of the "Kil", but it seems probable that the large reed stand in the eastern part (fig. 2) must have developed in the same way. In this stand itself no borings were made, but borings beneath the adjoining vegetation reveal the former presence of a Potamion succeeded by stands of Typha and of Equisetum fluviatile. Everywhere where Phragmites is found in soft mud or in deeper water, it has probably arrived there by the extension of stands growing nearer to the bank. This extension is effected by vegetative propagation. According to Birtmann (1953) Phragmites seeds may germinate in deeper water, but the seedlings are unable to maintain themselves in the latter.

Beneath the Caricetum gracilis-vesicariae two borings were made. Boring 6 was made beneath a vegetation in which Phragmites communis was well represented. Here the soil samples enlighten us only with regard to one preceding vegetation, viz. to the presence of a stand of Phragmites. Boring 13 was made beneath a vegetation in which Phragmites was absent, but here too in the clay mainly rests of Phragmites were found. Remains of Carex could not be detected, but this species will probably have made its appearance as soon as the frequencv of Phragmites began to decrease. The disappearance of Phragmites is probably due to human interference (mowing or grazing, cf. BiтTMANN 1953).

The results to which our study of the soil sample has led, may be summarized in the following eight points.

1) The first vegetation which established itself in the open water. belonged to the Potamion.

2) The facies of the Scirpeto-Phragmitetum which at present are the nrst to invade the Potamion, did so in the past too. 
3) Stands of Glyceria maxima and what we called the "mixed vegetation" begin to establish themselves as soon as the soft mud deposited by the preceding vegetation has reached a certain depth. The preceding vegetation is always a pioneer facies of the Scirpeto-Phragmitetum.

4) Floating mats owe their origin to the extension of a $T y p h a$ stand of which the rhizomes are rooting in the soil at the bottom of the pool. Where such Typha stands are or were lacking, no floating mats are or were ever formed.

5) The floating mats formed by the rhizomes of $T$ ypha angustifolia may grow out above stands of species belonging to the Potamion or over a stand of Equisetum fluviatile.

6) The more compact floating mats with Glyceria maxima or Phragmites communis as dominants develop out of the more loosely-textured mats formed by $T_{y}$ pha angustifolia. Phragmites invades the floating mats from adjoining stands consisting of plants rooting in the bottom of the pool.

7) The Phragmites stands find their starting point in the shallow water along the banks, and penetrate from there in the vegetation which established itself in deeper water but which, on account of the deposition of dead plant material, caused a rising of the bottom of the pool, which in this way became a suitable habitat for the invader.

8) The Caricetum gracilis-vesicariae is always preceded by a stand of Phragmites communis. In the "Kil" this community is not found in places where the bottom has been raised on account of natural processes including the activity of the vegetation. In the "Kil" the association therefore form no part of the hydrosere.

\section{THE TRANSFORMATION OF WATER INTO LAND}

By the aid of the findings on which we have reported above, it is possible to reconstruct the manner in which the open water of the former river bed was transformed into land.

The plant species which are the first to settle in the open water, belong to the Potamion. They give rise to the development of a vegetation in the shelter of which the bottom of the former river bed is gradually raised by the deposition of clay particles and of plant remains. The depth of the water, therefore, decreases, and the bottom becomes covered by a layer of loose soil. In the latter species of the Scirpeto-Phragmitetum begin to settle, and give rise to stands that are to be regarded as facies of this association. It are stands of Scirpus lacustris, of Equisetum fluviatile, of Sparganium erectum ssp. polyedrum and of Typha angustifolia. In these stands too the bottom continues to rise, and so, after some time, the soft mud on the latter becomes a suitable habitat for Glyceria maxima, which also forms stands, or for some other species which constitute what we have called the "mixed vegetation". When this zone borders on a stand of Phragmites, an invasion of the latter may take place. This may happen already in the period of the pioneer stands, but the invasion may also be postponed until the stands of Glyceria maxima or of the "mixed vegetation" have become established; 
in the long run the latter are always ousted by the expanding reed stands. In the "Kil" this is for the moment the last stage in the hydrosere. An indication of a further development into a Caricetum gracilisvesicariae is perhaps seen in an island some square meters in extent, which bears a stand of Carex acuta, and which is surrounded on every side by stands of reed and of Glyceria maxima rooting in soft mud.

A deviation of this mode of development may take place when in a stand of Typha angustifolia anchored in the soil at the bottom of the river bed the rhizomes grow out on the side of the open water into a floating mat. Why this happens, is so far unknown.

Such a floating mat consisting of the rhizomes of Typha angustifolia acquires a more solid consistence by the sedimentation of clay particles and of plant remains. Then, species adapted to less deep water begin to settle on it. In this way the aspect of the vegetation on the latter gradually changes. Typha angustifolia is replaced by $T$. latifolia, and later on by Glyceria maxima or by Phragmites. The last-mentioned species invades the mat from an adjoining stand rooting in shallow water.

Along the margin of the former river bed the layer of sand on which the clay rests, is found at a relatively slight depth (up to $1 \mathrm{~m}$. below the surface of the water). Here too in the period in which the bottom begins to rise, the site bears a vegetation belonging to the Potamion, but in this case the latter is immediately succeeded by a stand of Phragmites communis, by which the bottom is further raised. When it has been raised sufficiently by this facies of the Scirpeto-Phragmitetum, the latter is replaced by the Caricetum gracilis-vesicariae in which Phragmites still may determine the aspect. However, when cattle have access to it, or when it is regularly mown, Phragmites disappears.

The reconstruction given above of the way in which in this former river bed land develops out of open water, was based on our study of the soil samples collected in the bed. If we had tried to reconstruct it solely on the changes we observe in a transect extending from the open water to the bank, we would have misinterpreted the origin of some of the Phragmites stands belonging to the Scirpeto-Phragmitetum as well as that of the Caricetum gracilis-vesicariae, and the place which the stands of Glyceria maxima occupy in the succession, would have remained uncertain.

\section{TIME REQUIRED FOR THE TRANSFORMATION INTO LAND}

The Topographical Service, Delft, kindly placed at our disposition some aerial photographs of the area taken respectively in July 1937, in June 1947 and in February 1953. These photographs give us some information with regard to the rate at which the transformation of the open water into land proceeds. The situation revealed by the photograph taken in 1937 is shown in the drawing which is reproduced in Fig. 7.

In each of the photographs the reed stands and the vegetation belonging to the Potamion are at once recognizable; the other types of vegetation differ in tint, but what community each tint represents, 


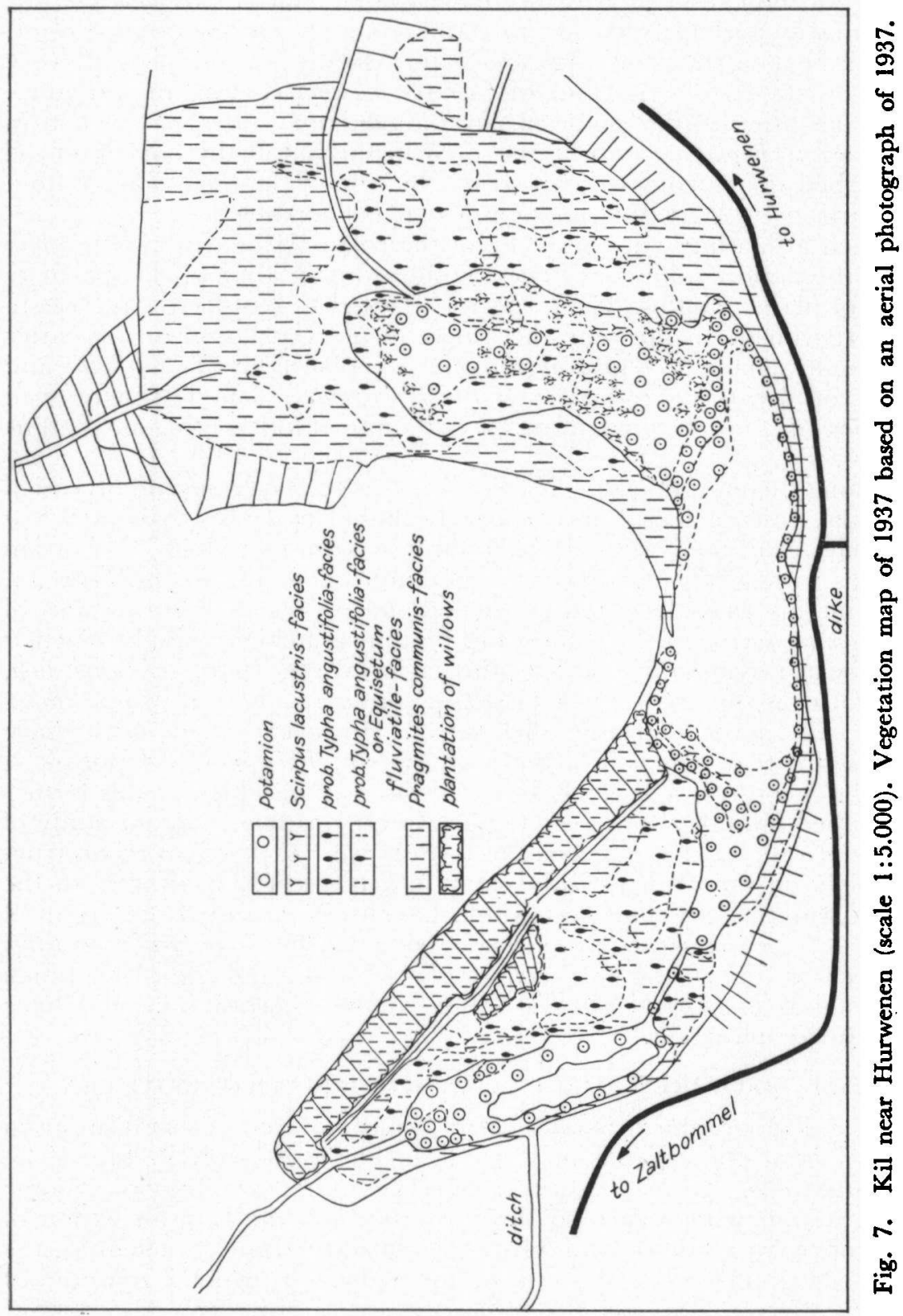


can be made out only by comparing the photographs with the situation as it exists at present and with that which is revealed by the analysis of the soil samples.

When we compare the situation as it appears in the photograph taken in 1937 (Fig. 7) with the vegetation map (Fig. 2) which was based on the situation as we found it in 1955, we arrive at the following conclusions.

In the eastern part of the "Kil" we see in 1937 a growth of hydrophytes, partly invaded by pioneer facies belonging to the ScirpetoPhragmitetum, viz. by a facies of Scirpus lacustris and one either of Typha angustifolia or of Equisetum fluviatile. The latter were surrounded by a stand of $T$ ypha angustifolia, whereas along the margin of the bed a belt of Phragmites was present. In 1955 the Phragmites belt along the margin had considerably increased in width, and in the centre of this part too an extensive stand of Phragmites had developed. In between we now find a mosaic formed by stands of Glyceria maxima and of the latter in combination with Typha latifolia. These stands are found partly on floating mats.

In the twenty years that have passed away since 1937 a vegetation consisting partly of hydrophytes and partly of pioneer facies of the Scirpeto-Phragmitetum was replaced therefore by stands of Glyceria maxima and of Phragmites.

In the northern part of the "Kil" where the water to the west of the plantation of willows is covered at present for the greater part by floating mats, we see that during this period the pioneer facies of Typha changed into floating mats bearing a dense stand of Typha whereas the dense stand of Typha rooting in the soil changed into stands of Glyceria maxima. Here too the belt of Phragmites underwent a considerable increase.

The unexpectedly rapid transformation of open water into land indicated by the differences seen in the aerial photographs, found confirmation in what an old farmer told us, viz. that thirty to forty years ago the farm hands when they went to milk the cows grazing on the other side of the pool, crossed the latter in the vicinity of the place where now the willow plantation is found, by means of a rowing boat. The willows were planted about thirty years ago.

\section{THE "WIEL" NEAR TUIL}

\section{INTRODUCTORY REMARKS}

The "Wiel" near Tuil, situated on the northern bank of the river Waal north of Zaltbommel (Fig. 1), consists of two pools connected by a ditch and separated from the river by the main dike. The pool on the southern side, which borders upon the dike, is used as a place for shooting rubbish, and is for this reason left out of consideration. The one on the northern side lies partly along a cart road called the "St. Anthoniussteeg". HoEksema (1947) says that these two pools owe their origin to a bent of the river Waal which by a "premature" embanking was shut off from the river, and which therefore was not 
filled up. According to VAN DER SLuYs (1957) too the "Wiel" would be a former bent of the river which however at the time it was shut off, presumably round the year 1300, was already partly filled up. However, at a later date the dike succumbed, and at that occasion a large part of the sediments were removed. This is in agreement with the name, which indicates a rather deep pool formed by the local rupture of a dike. On a map preserved in the "Maarten van Rossumhuis", the museum at Zaltbommel, a rupture of the dike is recorded which took place in the year 1663 at the spot where now the southern pool borders upon the dike. VAN DER SLUYs adds that at the place where the dike is in contact with the river levee of the former river bed, the soil consists partly of coarse sand, and that here on the bottom of the bed a powerful spring is found. The water produced by this spring is apparently supplied by the river, as the subsoil in the rest of the pools is rather impermeable.

The water in the pools is eutrophic. This eutrophy is probably kept up by the contact with the bottom in the centre, which consists of clay, and by the river water supplied by the powerful spring near the dike.

\section{DESGRIPTION OF THE VEGETATION}

\section{1. Potamion}

The floating and submersed hydrophytes in the "Wiel" belong to two communities of the Potamion. Record 18 (table III) gives us an idea of the first of these two communities, which is referred by us to the Myriophylleto-Nupharetum Koch 1926. The floating leaves of the plants belonging to this community cover nearly the whole surface of the northern pool. A wind-still corner is occupied by the Hydrochareto-Stratiotetum (van Langendonck 1935)Kr. et V1. 1937 (record 19).

\section{2. Sairpeto-Phragmitetum}

The pioneer facies of this association are represented only by stands of Scirpus lacustris and of Typha angustifolia. Each of them occurs but on a single spot, and covers but a small space. All the other communities that are included by us in the Scirpeto-Phragmitetum, are found here on floating mats only. Here too the mats with the looser texture bear Typha angustifolia as dominant species (record 20). The floating mats with the more compact texture bear a stand of Phragmites (record 21). Noteworthy is the total absence of Glyceria maxima and of Equisetum fluviatile. On those mats where, on account of the experience gained in the "Kil" at Hurwenen, we would expect the presence of Glyceria, we find instead of this species Carex riparia.

\subsection{Stands of Carex Riparia}

Some small floating mats bordering upon the Potamion bear stands of Carex riparia (record 22), but the latter also forms stands rooting in soft mud (record 23), i.e. in a habitat similar to that in which in the "Kil" at Hurwenen Glyceria maxima is found. A study of the lit- 
TABLe III

Wiel near Tuil

\begin{tabular}{|c|c|c|c|c|c|c|c|c|c|c|}
\hline $\begin{array}{l}\text { nr. of record } \\
\text { area in sq. } \mathrm{m} . \\
\text { cover in } \% \\
\text { water depth in } \mathrm{cm} .\end{array}$ & $\begin{array}{r}18 \\
3 \\
75 \\
25\end{array}$ & $\begin{array}{r}19 \\
16 \\
80 \\
?\end{array}$ & $\begin{array}{r}20 \\
2 \\
30 \\
0\end{array}$ & $\begin{array}{r}21 \\
4 \\
95 \\
30\end{array}$ & $\begin{array}{r}22 \\
2 \\
100\end{array}$ & $\begin{array}{r}23 \\
9 \\
85 \\
35 \\
\end{array}$ & $\begin{array}{r}24 \\
4 \\
100\end{array}$ & $\begin{array}{r}25 \\
100 \\
100\end{array}$ & $\begin{array}{r}26 \\
30 \\
80 \\
?\end{array}$ & $\begin{array}{r}27 \\
100 \\
45 \\
20\end{array}$ \\
\hline 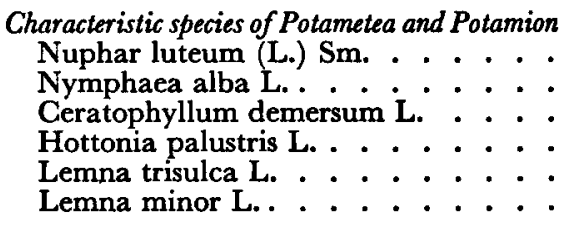 & $\begin{array}{r}2.2 \\
1.2 \\
\dot{3.3} \\
+.2\end{array}$ & $\begin{array}{r}1.2 \\
3.3 \\
+.1 \\
3.3 \\
+.2\end{array}$ & $\begin{array}{r}1.2 \\
1.2 \\
1.2 \\
2.2 \\
+.2\end{array}$ & $\begin{array}{c}+.2 \\
: \\
: \\
:\end{array}$ & : & $\begin{array}{r}\dot{ } \\
\dot{0} \\
+\dot{2}\end{array}$ & : & $\dot{:}$ & $\begin{array}{l}4.3 \\
: \\
:\end{array}$ & $\begin{array}{l}+.2 \\
\dot{.} \\
+. \dot{ } \\
+.2\end{array}$ \\
\hline 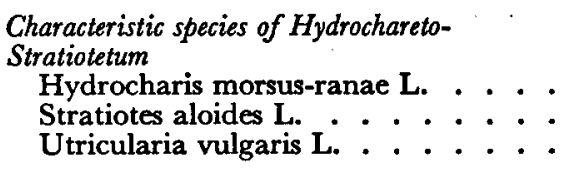 & $\begin{array}{c}+.2 \\
:\end{array}$ & $\begin{array}{c}2.2 \\
3.3 \\
\cdot\end{array}$ & $\stackrel{1.2}{:}$ & $\dot{.}$ & : & $\dot{.}$ & : & $\dot{:}$ & $\dot{5.5}$ & $\begin{array}{r}\dot{0} \\
+.2\end{array}$ \\
\hline 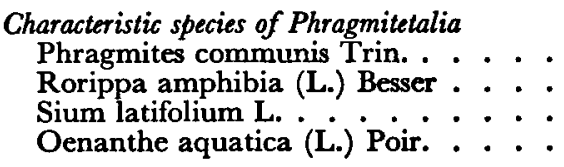 & : & $\begin{array}{l}1.2 \\
: \\
:\end{array}$ & $\dot{\bullet}$ & $\begin{array}{r}5.5 \\
+.2 \\
.\end{array}$ & $\begin{array}{r}1.2 \\
\dot{.} \\
+.1\end{array}$ & $\begin{array}{c}+.2 \\
: \\
:\end{array}$ & $\begin{array}{l}5.5 \\
: \\
\bullet\end{array}$ & $\begin{array}{r}4.5 \\
+.2 \\
+.2\end{array}$ & : & $\begin{array}{l}+.2 \\
+.2 \\
:\end{array}$ \\
\hline $\begin{array}{l}\text { Characteristic species of Phragmition and } \\
\text { Scirpeto-Phragmitetum } \\
\text { Typha angustifolia L. . . . . . . } \\
\text { Typha latifolia L. - . } \\
\text { Sparganium erectum L. ssp. polyedrum } \\
\text { (A. et G.) Sch. et Th. . . . . . }\end{array}$ & : & $\begin{array}{r}2.2 \\
+.2 \\
\\
.\end{array}$ & $\begin{array}{c}2.2 \\
\cdot\end{array}$ & : & $\begin{array}{l}\bullet \\
1.2\end{array}$ & $\begin{array}{l}+.2 \\
+.2\end{array}$ & $\begin{array}{r}+.2 \\
+.2\end{array}$ & : & - & $\dot{.}$ \\
\hline 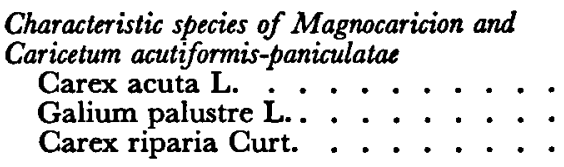 & : & $\vdots$ & : & $\begin{array}{r}\dot{0} \\
+\dot{2}\end{array}$ & $\dot{5}$ & $\dot{5.4}$ & $\begin{array}{l}1.2 \\
1.2 \\
1.2\end{array}$ & $\begin{array}{l}2.3 \\
1.2\end{array}$ & $\dot{\bullet}$ & $\dot{0}$ \\
\hline 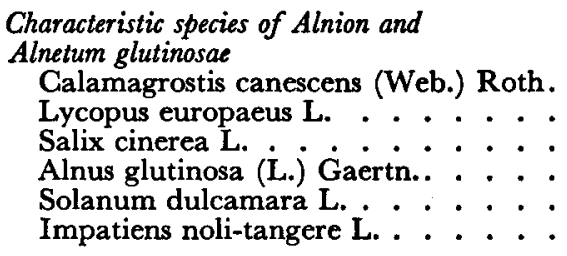 & $\dot{:}$ & $\dot{:}$ & $\begin{array}{r}+.1 \\
\dot{ } \\
\dot{ }\end{array}$ & : & $\dot{\bullet}: \dot{ }$ & $\begin{array}{r}\dot{ } \\
\dot{0} \\
+\dot{2}\end{array}$ & $\begin{array}{c}+\dot{0} \\
\vdots \\
1.2\end{array}$ & $\begin{array}{r}1.2 \\
+.1 \\
\dot{3.3} \\
\dot{\cdot}\end{array}$ & : & $\begin{array}{l}\dot{3.2} \\
\dot{\bullet}\end{array}$ \\
\hline 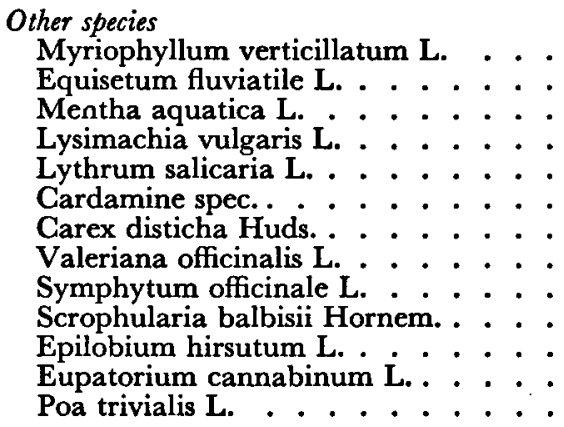 & $\begin{array}{l}1.2 \\
\vdots \\
\vdots \\
\vdots \\
\vdots \\
\vdots \\
\vdots\end{array}$ & $\dot{:}:$ & : & $\begin{array}{r}+\dot{2} \\
+\end{array}$ & 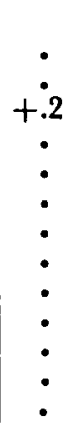 & : & $\begin{array}{r}\dot{0} \\
2.2 \\
+.2 \\
\dot{:} \\
\dot{0} \\
+.2 \\
1.2 \\
+.2 \\
:\end{array}$ & $\begin{array}{r}\bullet \\
1.2 \\
+.1 \\
1.2 \\
1.2 \\
: \\
: \\
\dot{1} \\
+.1 \\
+.2 \\
2.2\end{array}$ & : & $\dot{:}$ \\
\hline
\end{tabular}


erature (Boer, 1942; VAN Dijk and Westhoff, 1955; VAN DonselaAR, 1961) has convinced us that stands of the second kind are to be referred to the Caricetum acutiformis-paniculatae V1. et v. Z. B. 1942.

\section{4. Alnetum glutinosae}

When the texture of the floating mats becomes more compact, the vegetation borne by them undergoes a corresponding change (record 24). When they have become so solid that they can only be recognized as floating mats when borings are made, Alnus glutinosa makes its appearance on them (record 25). Between the floating mats with Alnus glutinosa small stretches of open water are found, in which Utricularia vulgaris occurs (record 26).

According to the literature (VAN Leeuwen, 1955) Salix cinerea would be one of the species that are met with in the Alnetum glutinosae. In the "Wiel" this species is also found, but not on the dry floating mats on which Alnus glutinosa occurs, but in water with a depth of 30 to $40 \mathrm{~cm}$. (record 27). The undergrowth consists of a sparse vegetation of Nuphar luteum and Carex riparia. These stands of Salix cinerea are interspersed between the floating mats in which Alnus has become established and the open spaces in which Utricularia is found.

In the "Wiel" the Alnetum glutinosae appears to be the last stage in the succession.

\section{FACTORS RESPONSIBLE FOR THE DIFFERENTIATION OF THE VEGETATION}

\section{1. Abiotic factors}

\section{1. 1. Depth of water}

It is doubtless allowed to assume that with regard to the Potamion and the communities belonging to the Scirpeto-Phragmitetum which are rooting in the soil at the bottom of the bed, the depth of the water plays in the "Wiel" a similar part as it does in the "Kil" at Hurwenen. With regard to the floating mats we have to admit that no sufficient data are available for drawing conclusions with regard to the effect which the height of the water column on top of them may have on the composition of their vegetation. As the decrease in height of the water column is always accompanied by an increase of the thickness of the floating mat, it is as yet impossible to say whether the changes in the composition of the vegetation which are taking place at the same time, are to be ascribed to the first-mentioned factor or to the second or to the joint influence of both factors.

\section{1.2. Consistence of the Soil}

The plants belonging to the two communities by which the Potamion is represented, as well as those belonging to the pioneer facies of the Scirpeto-Phragmitetum are rooting in or on a soft mud. Some of the Phragmites stands along the margin of the "Wiel" are rooting in a rigid clay under which at a comparatively slight depth a layer of 
coarse sand is found. The stand formed by Carex riparia as well as the community in which Salix cinerea predominates, grow in a soft mud consisting mainly of plant remains; clay is present in the latter in the form of a relatively unimportant admixture only. The other communities are rooting in floating mats. With the increase in thickness of the latter, their texture becomes firmer, so that in the end they become rather dry and form a solid substrate which is rich in humus.

\subsubsection{Composition of the soil}

Only in open water and underneath the communities belonging to the Potamion the upper layer of the soil consists of clay. In all other places it consists of a clayey peat, lower down passing into a peaty clay, and finally into clay. As the greater part of the vegetation is rooting in floating mats, the peat in the upper part of the soil on the bottom of the "Wiel" has on the whole no direct influence on the vegetation. Exceptions, however, are formed by the stand of Carex riparia and by the community in which Salix cinerea occupies the most prominent position.

\section{1.4. Chemical and physical properties of the water}

The chemical composition of the water was not determined. The vegetation is eutraphentous, and the $\mathrm{P}_{\mathrm{H}}$ is in agreement with this. It was determined in four places situated in different types of vegetation, and proved to vary between 7.3 and 7.6. Notwithstanding the presence of a thick layer of peat, the water remained eutrophic, and the $P_{\mathbf{H}}$ remained high.

In the same way as in the "Kil" at Hurwenen the $\mathrm{O}_{2}$-content of the water was determined. Here too it proved to decrease in the direction of the bottom and with the decrease in depth of the water.

\section{2. Biotic FACTORS}

\section{2. 1. Mode of rooting}

The way in which the various species are rooting, is the same as that observed in the "Kil" at Hurwenen, and the observations on the significance of this feature for the differentiation of the vegetation which were made in connection with the species occurring in the "Kil" are applicable here too. The only type of vegetation which was not present in the "Kil", is the stand of Carex riparia, and it is here therefore the place to give some particulars on the mode of rooting of this species.

Carex riparia is provided with rhizomes which may be followed over some distance. At some of the nodes new stems arise, which in their turn may send out some new rhizomes. Roots develop only at the places where the stems are produced, not on the other parts of the rhizomes.

The rhizomes of Carex riparia are found in rather rigid clay as well as in fairly soft mud. In the latter case this species behaves in the same way as Glyceria maxima does in the "Kil" at Hurwenen, i.e. it forms 
uniform stands in which only a few plants belonging to other species occur. As Carex riparia forms stands on floating mats too, the stands rooting in soft mud may easily be mistaken for stands growing on the latter. In every instance, therefore, we should make sure whether the plants are rooting in the soft mud on the bottom of the pool or not.

\subsubsection{Preceding stages in the succession}

Thick layers of clay containing plant remains, such as were found in the "Kil" at Hurwenen, are absent in the "Wiel". As the area in which the latter is found, lies behind the main dike, it is no longer flooded by the river Waal, and there is therefore no clay deposited. Instead we find peaty layers, and in the latter the plant remains were identified.

In samples collected below open water a homogeneous black mud was found in which with the naked eye no plant remains are recognizable; the same kind of mud was found also in samples collected underneath the Myriophylleto-Nupharetum.

The facies of Scirpus lacustris appears to be rooting in a $30 \mathrm{~cm}$. thick Iayer of soft mud (boring 14, fig. 6c). Below the latter we find clay with remains of $\mathcal{N}$ uphar luteum or of Nymphaea alba and some of Stratiotes aloides. The last-mentioned species occurs to this day in this corner of the pool in the immediate vicinity of the stand of Scirpus lacustris.

Below the floating mat with the stand of Typha angustifolia the column of water appeared to have a height of $1.20 \mathrm{~m}$. The mud below the latter was not investigated. An adjoining floating mat, which was $30 \mathrm{~cm}$. thick and bore a vegetation consisting of Typha angustifolia, Phragmites communis and Carex riparia, proved to rest on a water column with a height of $30 \mathrm{~cm}$., which in its turn rested on a 1.00 to $1.20 \mathrm{~m}$. thick layer of peat. In the lowermost part of the latter remains of Nuphar luteum or Nymphaea alba were found, but the rest consisted mainly of remains of Stratiotes aloides; in the uppermost part some fragments of Typha spec. and of Phragmites were present (boring 15). Below an even more compact floating mat with a vegetation of Phragmites the peat layer proved to consist also of Stratiotes aloides, but here throughout the whole layer remains of Phragmites and some fragments of Typha were recognizable (boring 16, rec. 24).

The floating mat on which Alnus glutinosa had established itself, rested on a $50 \mathrm{~cm}$. high column of water. The peat layer below the latter consisted in the lowermost part of remains of Nuphar luteum or Nymphaea alba, for the rest of Stratiotes aloides, with in the uppermost zone some remains of Typha; Phragmites occurred in the peat to a depth of $20 \mathrm{~cm}$. (boring 17 , rec. 25).

A boring made below the stand of Carex riparia shows that the preceding vegetation consisted here almost entirely of Stratiotes aloides. Carex riparia apparently established itself on the layer of peat formed by the latter (boring 18, fig. 6d, rec. 23).

A similar situation is met with under the stand of Salix cinerea, but here we find in the uppermost layer of the peat a large number of leaves of Salix cinerea itself (boring 19, rec. 27). 
In some places a belt of Phragmites is found which appears to be rooting in a layer of peat of which the lowermost part consists of remains of Nuphar or Nymphaea, the rest mainly of remains of Phragmites itself (boring 20).

\section{THE TRANSFORMATION OF WATER INTO LAND'}

The borings which were made in the "Wiel", have revealed that the whole vegetation, with the exception of the stand of Carex riparia, the community with Salix cinerea, and the reed belt along the margin, is borne by floating mats.

From the way in which the vegetation on the floating mats is divided in belts, we are inclined to conclude that here too the foundation of the floating mats was laid by Typha angustifolia. We have to admit, however, that the composition of the peat found underneath the floating mats gave us no confirmation of this view, although the data are not irreconcilable with it either. At any rate remains of the Typha stands which by the growing out of their rhizomes into the open water would have produced the floating mats, were not found in the upper part of the peat deposit. It is true that fragments of Typha were present, but they formed a minor part only of the total amount of plant remains, and several other species were better represented among the latter.

Totally unexpected was the finding that the major part of the peat consists of remains of Stratiotes aloides, a species which at present is rather poorly represented.

In the literature (Boer, 1942; VAN Zinderen Bakker, 1942) a succession has been described which starts with a stand of Stratiotes aloides, and which by way of the Cicuteto-Caricetum pseudocyperus and the Caricetum acutiformis-paniculatae leads to an Alnetum glutinosae. However, in the present vegetation of the "Wiel" as well as in the peat deposits at the bottom the Cicuteto-Caricetum pseudocyperus is entirely absent. It is possible, of course, that it has been present at an earlier date, but that its remains have disappeared. In that case Typha angustifolia might have settled in floating mats that had been formed by Cicuta virosa. The typical Caricetum acutiformis-paniculatae, which in the succession would follow on the Cicuteto-Caricetum pseudocyperus, is also absent in the "Wiel". It is true that the stands of Carex riparia are included by us in this association, but these stands do not occur on floating mats, as they ought to do if they actually belonged to this succession, but they are rooting in the soft mud at the bottom of the pool. This mud was formed, as we have seen above, by a stand of Stratiotes.

The preceding considerations show that neither the arrangement of the present vegetation in different belts nor the composition of the peat found on the bottom of the "Wiel" enable us to give a definite answer to the question in what way in this case the open water was transformed into land. The most plausible assumption seems to be that Carex riparia established itself directly on the remains of Stratiotes aloides, and that the floating mats owe their origin to rhizomes of Typha angustifolia which grew out into the open water, i.e. that they 
arose in the same way as the floating mats in the "Kil" at Hurwenen.

In the "Wiel" at Tuil as in the "Kil" at Hurwenen the factors which are of primary importance for the differentiation of the vegetation, are therefore the depth of the water and the consistence of the soil at the bottom as well as that of the floating mats, although the composition of the soil and the nature of the preceding vegetation will also have played a part.

\section{THE "KIL" NEAR WAARDENBURG}

\section{INTRODUCTORY REMARKS}

The "Kil" at Waardenburg, situated on the northern bank of the river Waal north of Zaltbommel (fig. 1), borders on the land side upon the slope of the main dike. On the other side the "Kil" borders up on comparatively high grounds planted with willows and shut off from the river by a summer dike. The remains of the former river bed and these plantations of willows make a fine landscape which becomes even more attractive by the presence of an old castle and a windmill on the dike and of a wood on the inside of the latter. The railway from Utrecht to 's-Hertogenbosch divides the "Kil" into an eastern and a western part. The eastern part was studied by us. Its position with regard to the direction of the river is such that in times of flood it will probably be exposed to a comparatively strong current.

\section{DESCRIPTION OF THE VEGETATION}

\section{1. Potamion}

Species belonging to the Myriophylleto-Nupharetum as well as to the Polygoneto- $\mathcal{N}$ ymphoidetum and the Hydrochareto-Stratiotetum are present. Together they form a mosaic in which no definite pattern is recognizable.

\section{2. Scirpeto-Phragmitetum and Garicetum gracilis-vesicariae}

In the deeper parts the Scirpeto-Phragmitetum is represented by the facies of Scirpus lacustris and by that of Sparganium erectum ssp. polyedrum. At the side of the dike the "Kil" is bordered mainly by a belt of Phragmites. On some parts of the opposite side stands of Typha angustifolia are met with. On the eastern and on the western end we find stands of Glyceria maxima, bordering towards the open water on stands of Typha angustifolia. In shallow spots fragments of the Caricetum gracilis-vesicariae are present. Where the "Kil" is accessible to cattle, a facies of Oenanthe aquatica occurs; according to VAN DonselaAR (1961) this vegetation should be included in the Scirpeto-Phragmitetum. Typha latifolia and floating mats are absent.

3. FACTORS RESPONSIBLE FOR THE DIFFERENTIATION OF THE VEGETATION

Only two borings could be made, of which one was analysed (boring 21, fig.6d). It was obtained from a stand of Glyceria maxima at one 
of the ends of the "Kil". The collection of plant remains found at different depths in the clay shows a considerable difference in composition, the dominant species being continually replaced by others. It seems probable, therefore, that the remains are not autochthonous, and that they can not enlighten us therefore with regard to the succession at the place of the boring.

By combining what we found at the "Kil" at Hurwenen with regard to the mode of rooting of the various species, with what we know with regard to the force of the current in different parts of the pool, we can understand to some extent in what way the differences in the development of the vegetation must have been brought about.

Where during the period of flood the current in the "Kil" at Waardenburg is strongest, and where therefore little or no sedimentation of clay particles and of plant remains takes place, i.e. on the side turned towards the main dike, only stands of Phragmites and of Scirpus lacustris are found. These species are provided with rhizomes that are firmly anchored in the soil, and which accordingly are not easily uprooted by the current. Typha angustifolia thrives only in a soft soil, and is therefore easily uprooted; accordingly it can maintain itself only at the two ends of the pool and in the bent on the inside where the current is less strong. As the sedimentation of clay particles and of plant remains is confined to the two ends of the pool, this are the only parts where stands of Glyceria maxima have been able to establish themselves. Here we find in the direction of the bank first a belt of Typha angustifolia, then one of Glyceria maxima, and finally one of Phragmites communis, and this may perhaps be regarded as a reflection of the succession. In other parts of the pool the zonation is determined entirely by the depth of the water, and as the latter does not change, a succession of the kind found in the "Kil" of Hurwenen plays here no part.

The presence of Sparganium erectum in this pool is unexpected. It is found here in places where during the period of flood certainly a current must be present. For this reason it would be desirable to investigate the development of the root system on one of these places. On account of technical difficulties such an investigation could not yet be carried out.

\section{DISGUSSION OF THE FACTORS BY WHICH THE DIFFERENTIATION OF THE VEGETATION IN THE FORMER RIVER BEDS IS DETERMINED}

The belts in which the vegetation in the "Kil" near Hurwenen and in the "Wiel" near Tuil is differentiated, are determined, as we have seen, in the first place by the depth of the water. When the latter decreases, the Potamion is replaced by the pioneer facies of the ScirpetoPhragmitetum, and when the depth decreases still more, these pioneer facies are replaced by other facies or by a community belonging to this association which comprises a larger number of species. The 
passage of the Scirpeto-Phragmitetum into the Caricetum gracilis-vesicariae, however, does not depend entirely upon a further decrease of the depth, but also upon an increase in the solidity of the soil.

The stands of Glyceria maxima, our "mixed vegetation" and probably the stands of Carex riparia too require, on the other hand, apart from a certain depth of the water, a softer soil.

The differentiation which we observe within the Scirpeto-Phragmitetum, is, apart from the depth of the water, determined in the main by a more or less accidental circumstance, viz. by the fact to what species the individuals belong which first succeed in establishing themselves on the site. On account of the strong vegetative propagation by means of the rhizome such individuals may grow out into stands of a more or less considerable extent. This vegetative propagation is therefore responsible for a splitting up of the area which is suitable to the development of the association into parts occupied in the main by single species, i.e. for the development of the various facies of the association.

In the "Kil" at Waardenburg still another factor is involved in the differentiation of the vegetation, viz. the force of the current to which the latter is exposed during the period in which the area in which the "Kil" is situated, is flooded by the river Waal. On account of this current, species which are not very firmly anchored in the soil at the bottom of the pool, are confined to the parts which are more or less protected against the force of the current, whereas in parts where the latter is very strong, only those species can maintain themselves which are very firmly anchored.

\section{DISGUSSION OF THE FACTORS BY WHICH THE DIFERENCES BETWEEN THE VEGETATION IN THE VARIOUS FORMER RIVER BEDS ARE DETERMINED}

The differences in the position which the former river beds at Hurwenen, Waardenburg and Tuil occupy with regard to the present river bed, give us some indications with regard to the factors which must have played a part in the development of the differences in the vegetation which at present is found in these pools.

The "Wiel" at Tuil is situated inside the main dike, whereas the "Kil" at Hurwenen and the "Kil" at Waardenburg are found outside the main dike. During the yearly returning period of flood the two last-mentioned pools are therefore in contact with the river; for this reason their water remains eutrophic, and the vegetation, which is responsible for the decrease in depth and for the transformation of the marginal zone into land, remains eutraphentous. The area in which the "Wiel" is situated, is no longer flooded, and this pool lacks therefore the yearly supply with eutrophic water. Under these circumstances one would expect that under the influence of the vegetation the $P_{H}$ of the water would gradually decrease, and that the latter, moreover, would become oligotrophic. We have seen, however, that this is not so; the water in the "Wiel" is in reality eutrophic and 
does not differ in its $\mathbf{P}_{\mathrm{H}}$ from that of the former river beds at Hurwenen and at Waardenburg; here too the vegetation accordingly remains eutraphentous. All this is probably due to the contact of the water with the clay bottom in the central part of the pool, and to the presence of a spring near the dike which is apparently fed by river water.

The absence of the yearly flood is nevertheless not without importance, as with the supply of river water the supply of clay particles too was stopped. The upper part of the soil at the bottom of the pool contains therefore but very little clay, and consists mainly of plant remains. The peat in the "Wiel" is accordingly deposited in a eutrophic medium. However, the presence of this peat can influence only those species that are rooting in it, i.e. the stands of Carex riparia and of Salix cinerea. It might do this either through its chemical composition or through its softness, but this is a problem that remains as yet unsolved.

There is still another way in which the contact with the river during the period of flood may influence the vegetation, viz. by means of the current which it creates in the pools. In the "Kil" at Waardenburg this current is rather strong, in the "Kil" at Hurwenen, on the other hand, it is hardly noticeable. In the "Kil" at Waardenburg the force of the current actually is an important factor in the distribution of those species which differ in the firmness with which they are anchored in the soil. It may also be responsible for the absence of Typha latifolia and of floating mats in this pool. Another result of a strong current is that no sediments are formed; in the "Kil" at Waardenburg the latter are deposited only in spots that are protected against the force of the current.

In the "Kil" at Hurwenen the force of the current is, as stated above, negligible, and accordingly the zonation of the vegetation shows no features that might be due to the latter. The two Typha species are both present in large numbers, and $T$. angustifolia even forms floating mats. Clay and plant remains are deposited in all parts of the pool, and cause a gradual decrease in depth which is reflected in the succession.

In the "Wiel" at Tuil there is, of course, no current at all. Typha angustifolia and $T$. latifolia are both present, and the major part of the vegetation rests on floating mats. It is the only pool in which an Alnetum glutinosae is present. According to Van LeEuWen (1955), Alnus glutinosa is unable to establish itself in the winter bed of the larger rivers. $\mathrm{He}$ is of opinion (oral communication) that this may be due to the destructive action of passing ice floes. Further, extensive stands of Carex riparia are present, which are also lacking in the two other pools. Whether and in what way this may be connected with the absence of a current, is not clear. It may be that the large amount of peat in the soil acts here as the decisive factor.

Our conclusions with regard to the differences observed between the vegetation in the three pools may be summarized therefore in the following way. 
The difference is due in the first place to the presence or absence of a current, and to the force of the latter, during the period of flood. In this way a selection is exercised between species which differ in the firmness with which they are rooted in the soil.

The absence of a current is also responsible for a difference in the composition of the material which is deposited on the bottom (clay with peat or peat alone), and this too may be of importance.

\section{SUMMARY}

In three former river beds of the river Waal near Zaltbommel a study was made of the factors which determine the differentiation in the vegetation.

The water in each of the three beds is eutrophic. One of the beds is situated inside the main dike of the present river, the two other ones outside the latter, i.e. in the area which is exposed to the yearly returning foods. In only one of the two former river beds outside the dike a current is noticeable during these periods. At that time clay is deposited, and the bottom of these two beds accordingly consists of clay. In the former bed that is protected against these floods by the dike, only in the central part of the bottom the clay is still exposed, whereas nearer to the bank it is covered by a layer of peat.

The vegetation in so far as it might be regarded as a natural one, was studied in detail, and appeared to consist in the main of a community belonging to the Potamion (in the deeper part), pioneer facies of the Scirpeto-Phragmitetum (Phragmition), later stages in the development of this association (a.o. "floating mat"-communities), one belonging to the Magnocaricion (in the shallower water), and, in the case of the former bed inside the dike, a carr-wood. The vegetation varied, however, in the different beds and eventually also in different parts of the same bed.

The way in which the vegetation in the three former river beds differs, appeared to depend i.a. on the degree in which the various species are able to resist the current, and this mainly depends on their way of rooting. Only species like Phragmites and Scirpus lacustris can maintain themselves in places that are exposed to a strong current, because they are firmly anchored in the soil. Weakly anchored species like the twc Typha's are found only in places where there is no current, and the development of floating mats is possible only in stagnant water.

Apart from the presence or absence of a current, important factors are the depth of the water and the consistence of the soil in which the plants are rooting. The correlation between the depth of the water and the nature of the vegetation appears in the succession of the Potamion by way of the pioneer facies of the ScirpetoPhragmitetum to the later stages in the development of this association. In less deep water the consistence of the soil comes to the fore. In the former beds outside the dike the vegetations belonging to the Scirpeto-Phragmitetum grow on a muddy soil showing little or no cohesion, but the Caricetum gracilis-vesicariae (Magnocaricion) is confined to soils showing a higher degree of rigidity.

Of great importance is the faculty to multiply vegetatively by means of rhizomes, which is found everywhere where a definite species determines the character of the vegetation, i.e. where a definite facies is present. This applies to the vegetations found on the floating mats too, which possess a frame work consisting of rhizomes. At first the latter belong exclusively to Typha angustifolia, but in subsequent stages of their development rhizomes of other species too take part in the development of this frame work. In the course of their development these floating mats may reach a considerable thickness. This growth in thickness is accompanied by a change in the type of vegetation. In the bed behind the dike the floating mats are particularly well-developed, but at places where in this bed no floating mats are present, the plant remains sink to the bottom, where they give rise to the formation of a layer of peat. On the latter a vegetation of Carex riparia, representing the Magnocaricion, and a Salix cinerea-stand develops.

The plant remains found in the bottom (peat as well as clay) were studied by the aid of the microscope, and in this way it proved possible to reconstruct the 
succession in the beds, except in those places where during the period of flood a current is present, because in that case the plant remains are swept away. It was proved that a vegetation belonging to the Potamion appeared first and was always succeeded by pioneer-facies of the Scirpeto-Phragmitetum, eventually followed by later stages in the development of this association. The Caricetum gracilis-vesicariae, on the other hand, was no stage in this succession, but developed in the shallow water of the marginal zone on a bare soil. The floating mats in their initial stage appeared to develop as an extension of a Typha angustifolia-vegetation rooting in the bottom, overgrowing subsequently the pioneer facies of Equisetum fluviatile and/or a Potamion-vegetation. Other species settled on the floating mat as soon as it attained a certain thickness because of sedimentation of clay and/or plant remains.

Below the floating mats in the bed behind the dike a layer of peat was found which proved to consist of remains of Stratiotes aloides, a species which at present is met here but rarely. Peat of the same composition was also present below the open spaces between the floating mats, i.e. on the spots where the vegetation of Carex riparia and that of Salix cinerea is found.

\section{REFERENGES}

Baren, J. van, 1927. Drijftillen. In: De bodem van Nederland 2: 933-939. Amsterdam.

Bitrmann, E. ,1953. Das Schilf (Phragmites communis Trin.) und seine Verwendung im Wasserbau. Angewandte Pflanzensoz. 3: 1-203.

BurNK, H., 1891. De lage venen in Nederland en het ontstaan der drijftillen. Tijdschr. Kon. Ned. Aardr. Gen. 2nd ser. 8: 683-719.

Boer, A. C., 1942. Plantensociologische beschrijving van de orde der Phragmitetalia. Ned. Kruidk. Arch. 52: 237-303.

Braun-Blanquet, J., 1951. Pflanzensoziologie. 2nd ed. Vienna.

DiJK, J. VAN and V. Westhofr, 1955. De plantengroei der natuurgebieden in N.W. Overijsel. Natuur en Landschap 9, 2: 33-57.

DonselaAR, J. van, 1961. On the vegetation of former river beds in the Netherlands. Wentia 5: 1-85.

Edelman, G. H. c.s., 1950. Een bodemkartering van de Bommelerwaard boven de Meidijk. Versl. Landbouwk. Onderz. 56, 18. The Hague.

ETTER, H., 1949. De l'analyse statistique des tableaux de végétation. Vegetatio $1: 147$.

HoEkSEMA, K. J., 1947. Verlande stroombeddingen in het rivierkleigebied en haar benamingen. Tijdschr. Kon. Ned. Aardr. Gen. 64, 1: 40-46 and Boor en Spade 2: 102-108 (1948).

Jennings, J. and J. M. LAMBERT, 1951. Alluvial stratigraphy and vegetational succession in the region of the Bure Valley Broads. J. Ecol. 39. I. J. and L: Surface features and general stratigraphy (106-119). II. L. and J.: Detailed vegetational-stratigraphical relationships (120-148). III. L.: Classification, status and distribution of the communities (149-170).

LeEuWEN, GHR. v., 1955. Beplantingen op vegetatiekundige grondslag. Report in archives of RIVON, Bilthoven-Noord; not publ.

MeIjer, W. and R. J. DE WIT, 1955. Kortenhoef. Een veldbiologische studie van een Hollands verlandingsgebied. Ed. Stichting "Commissie van de Vecht en het O. en W. Plassengebied". Amsterdam.

Migahid, A. M., 1947. An ecological study of the "Sudd" swamps of the Upper Nile. Proc. Egypt. Acad. Sc. 3: 57-87.

Orsen, S., 1959. Aquatic plants and hydrospheric factors. Svensk Bot. Tidskr. 44. I. Aquatic plants in S.W. Jutland, Denmark (1-34). II. The hydrospheric types (332-372).

RuttNer, Fr., 1952. Grundriss der Limnologie. 2nd ed. Berlin.

Schierbeek, A., 1917. De studie der venen. Tijdschr. Kon. Ned. Aardr. Gen. 2nd ser. 34: 505-546. 1926-1927. De waterklaver als drijftilvormer. De Levende Natuur: 263-267.

SluYs, P. van DER, 1957. De bodemkartering van de Tielerwaard West. Driemaandelijks bericht komgrondengebieden 7: 19-33. Ed. Stichting ontwikkeling komgrondengebieden. 
Tüxen, R., 1937. Die Pflanzengesellschaften Nordwestdeutschlands. Mitt. Florist.soz. Arbeitsgem. in Niedersachsen 3: 1-203.

Warming, E., 1909. Oecology of plants. Oxford.

Westhoff, V., J. W. Dijk, H. Passchier and G. Sissingh, 1946. Overzicht der plantengemeenschappen in Nederland. 2nd ed. Amsterdam.

Westhofr, V. c.s., 1949. Landschap, flora en vegetatie van de Botshol nabij Abcoude. Ed. Stichting "Commissie van de Vecht en het O. en W. Plassengebied". Baambrugge.

WoERdT, D. VAN DER and D. M. DE VRIEs, 1948. De botanische samenstelling van de uiterwaarden en de overeenkomstige binnendijks gelegen gronden. Landbouwk. Tijdschr. 60, 11-12: 584-590.

ZiNDEREN BAKKER, E. M. vaN, 1936. Het botanisch onderzoek van het Naardermeer. Jb. Ver. Behoud van Natuurmon. in Ned. 1929-1935: 159-171. 1942 a. Het Naardermeer. Amsterdam. 1942 b. Successie onderzoek in het Naardermeer. De Levende Natuur 47, $1 / 2: 1-10$.

Zonneveld, I. S., 1952. De Biesbosch, een zoetwatergetijdendelta. Natuur en Landschap 6, 2 and 3: 170-182, 205-221.

1955. Over natuurreservaten in de Biesbosch en het Deltaplan. Natuur en Landschap 9, 4: 113-128. 